\title{
The 'competition-stability/fragility' nexus: A comparative analysis of Islamic and conventional banks
}

\author{
Md. Nurul Kabir ${ }^{a^{*}}$, Andrew C. Worthington ${ }^{\mathrm{b}}$ \\ a Charles Darwin University Business School, Charles Darwin University, Australia. \\ ${ }^{\mathrm{b}}$ Department of Accounting Finance and Economics, Griffith Business School, \\ Griffith University, Australia.
}

\begin{abstract}
The 'competition-stability/fragility' nexus is one of the more debated issues in the banking literature. However, while there is ample evidence concerning the relationship between competition and stability/fragility in different countries and regions, no prior study investigates this in the context of Islamic and conventional banks. We do this using data on both types of banks drawn from 16 developing economies over the period 2000-12. We measure the lack of competition using the Lerner index, and stability using both accountingbased measures, comprising the Z-score and the nonperforming loan ratio, and market-based measures, including Merton's distance to default. We employ panel vector autoregression and two-stage quantile regression to estimate the relationship. Our results lend support to the competition-fragility hypothesis in both Islamic and conventional banks. We also find the magnitude of the market power effect on stability is greater for conventional banks than Islamic banks. Lastly, banks in the median quantile of stability have a greater ability to reduce credit risk through gaining market power than banks in the lower and upper quantiles.
\end{abstract}

JEL classification: G21; G28; G32

Keywords: Competition, Stability, Lerner index, Panel vector autoregression, Z-score, Distance-to-default

\footnotetext{
* Corresponding author. Charles Darwin University-Sydney, Level 9, 815 George Street, Haymarket NSW 2000, Australia. Tel.: +61 280474141

E-mail addresses: mdnurul.kabir@cdu.edu.au (Md. Nurul Kabir), a.worthington@griffith.edu.au (A.C. Worthington).
} 


\section{Introduction}

In just a few decades, Islamic banking has grown worldwide at a rate of nearly 15-20 percent annually. This has attracted the attention of policymakers, regulators, and investors, particularly after the recent global financial crisis, when the possibility emerged that Islamic banking could serve as a viable alternative to the conventional banking system. According to a recent survey, in 2013 alone, global Shariahcompliant assets increased by $8.67 \%$ and the aggregate return on assets (ROA) for Islamic banks was about $1.47 \%$, with about 349 Islamic financial institutions offering their services worldwide, up from less than a score two decades earlier (Banker, 2013). The rapid growth of Islamic financial institutions naturally raises questions concerning the sustainability of the Islamic banking system in the longer run.

The impact of competition on stability in the banking sector is one of the more debated issues among academics and policymakers. On one hand, the literature argues that excessive competition can erode the franchise value of banks leading to financial fragility (Ariss, 2010b; Besanko and Thakor, 1993; Keeley, 1990). On the other, competition can also enhance bank stability through bringing about efficiency, promoting new product innovation and enhancing loan portfolio diversification (Caminal and Matutes, 2002; Fiordelisi and Mare, 2014; Nicoló et al., 2006). Both views enjoy strong theoretical and empirical support. Research has also recently emerged investigating this competition-stability/fragility hypothesis in different economies and over different periods, with the existing results described best as mixed in that there are no conclusive findings concerning either view.

In most economies, Islamic and conventional banks compete with each other. Further, many conventional banks have recently installed Islamic banking 'windows' to further 
intensify competition. Competition also arises not only from domestic conventional banks, but also from foreign banks, which also may adopt this Islamic banking strategy. On the plus side, Islamic banks will bring to the market more innovative Shariah-compatible financial products; on the downside, this excess competition may have a detrimental effect on their long-run sustainability (Ariss, 2010a). Based on this background, we present research questions as follows. First, does competition enhance financial stability in Islamic and conventional banking systems? Second, in light of this, do regulators need to undertake separate competition policy for Islamic and conventional banks? Responding to these questions through examining the competition-stability/fragility hypothesis in the context of Islamic and conventional banks will have important policy implications for both regulators and practitioners, especially in those economies where both banking systems coexist.

A number of prior studies have investigated the financial stability of Islamic and conventional banks using a number of different techniques and contexts. While a few find that Islamic banks are less stable than conventional banks, others conclude that Islamic banks are more stable, especially small Islamic banks when compared with both conventional banks and large Islamic banks (Abedifar et al., 2013; Beck et al., 2013; Čihák and Hesse, 2010). Conversely, existing studies that have investigated the level of competition between Islamic and conventional banks have mixed conclusions. For example, Ariss (2010a) argues that Islamic banks have more market power than conventional banks whereas Weill (2011) finds that there is no significant difference between Islamic and conventional banks in terms of competition. However, to the best of our knowledge, no prior study has investigated the competitionstability/fragility nexus by comparing Islamic and conventional banks. Our research aims to shed light on the relation between competition and stability in both Islamic 
and conventional banks. Combining these two strands of the literature should provide an indication as to whether Islamic banks are both less competitive and/or more stable than conventional banks.

To investigate the 'competition-stability/fragility hypothesis, we select 16 national banking systems where both Islamic and conventional banks operate during the period 2000-2012. The empirical procedure is as follows. First, we measure market power (i.e., the lack of competition) for each bank using the Lerner index (LI), with a higher LI value indicating less market competition. Compared with other methods of measuring competition, the LI is generally more suitable than other measurements because we can calculate it at the individual bank level, and it is therefore more informative. Second, we measure the level of financial stability using two accountingbased credit risk measures, namely, the Z-score and the nonperforming loan (NPL) ratio, and a market-based credit risk measure, in the form of Merton's distance to default (DD) model. Employing both accounting- and market-based measures of stability should yield robust findings on the precise relationship between competition and stability.

Third, we then use panel vector autoregressive (PVAR) estimation methods to describe the relationship between competition and stability. As both our variables of interest (competition and stability) are endogenous (Anginer et al., 2014; Schaeck and Cihák, 2014), PVAR is a suitable estimation technique as it allows the relationship between the variables to be endogenous and does not require a specific a priori relationship between them. We also derive impulse response functions (IRF) and undertake variance decomposition through which we investigate how the shock of one variable affects the other variable in future periods. According to Schaeck and Cihák (2014) and Dima et al. (2014), the response of riskier banks may significantly differ 
from that of more stable banks when competition increases or decreases. Thus, we specify two-stage quantile regressions by which we can identify the impact of competition at different stability levels for both Islamic and conventional banks.

Our PVAR estimation technique provides some interesting results concerning the relationship between competition and stability. First, we identify a consistent Granger-causality effect between market power and stability. Second, our empirical evidence shows that market power is positively associated with stability. This in turn lends support to the competition-fragility hypothesis in that low competition (i.e. high market power) increases stability. This result is consistent across the three stability proxies. Third, among these, the Lerner index has a long-term impact on the NPL ratio, whereas its impact on the Z-score and DD is more short term. Complementary analysis using two-stage quantile regressions also reveals some interesting results. First, consistent with our previous findings, the two-stage quantile regression results indicate that market power has a positive and significant impact on stability in both Islamic and conventional banks for all three proxies of stability, thus supporting the competition-fragility hypothesis. Second, the magnitude of the effect (i.e. the estimated coefficient of the Lerner index) is higher for conventional banks than Islamic banks. Third, the significance level of the impact on stability is weaker for Islamic banks than for conventional banks. Fourth, the impact of market power on stability varies significantly across the different quantiles for the alternative systems. Finally, it appears that banks in both banking systems at the median quantile have a better ability to reduce credit risk through gaining market power than banks in the lower and upper quantiles.

Our contribution to the literature is threefold. First, this is the first study to investigate the impact of competition on stability in the context of both Islamic and conventional 
banks using an international sample. For the most part, prior studies investigate stability and market power separately, with no study considering both conventional and Islamic banks. Second, we calculate both accounting and market-based stability measures. Critics argue that accounting-based measures, although very popular, may not be good proxies for stability as they yield only a backward-looking assessment and do not incorporate future expectations. To overcome these problems and to yield robust evidence, we employ both accounting- and market-based credit risk proxies. Lastly, we use two different methodologies, namely, PVAR and two-stage quantile regression, to estimate the relationship between competition and stability. These methodologies capture different dimensions and the relationship between competition and stability, and thereby provide a more comprehensive analysis. In addition, both methods are capable of dealing with the problem of endogeneity in the estimation process.

Our research has a number of policy implications. First, it suggests regulating competition in economies where both Islamic and conventional banks coexist given market power has a significant positive impact on stability. Second, the impact of market power on stability significantly varies across different levels of bank stability, so regulators should consider the effects of any competition regulation policy on the health of the banks. Finally, as both banking systems follow the competition-fragility hypothesis, our results do not suggest the necessity of separate competition regulation for the two banking systems.

The remainder of the paper is structured as follows. Section 2 discusses the literature and Section 3 describes the methodology. Section 4 details the descriptive statistics and Section 5 provides the empirical results. Section 6 concludes. 


\section{Literature Review}

\subsection{Theoretical Evidence}

As argued by Carletti (2008) and Berger, Klapper, and Turk-Ariss (2009), there are two opposing views regarding the relationship between competition and stability in the banking sector. Both have strong theoretical and empirical evidence supporting their claims. In this section, we briefly describe the theoretical evidence supporting the competition-fragility and competition-stability hypotheses. In seminal work, Keeley (1990) triggered debate on the competition-fragility relation by showing that the failure of a large number of US banks resulted from deregulation in the banking industry. Using a state preference model, Keeley (1990) showed that an increase in competition accounted for a decline in the charter value of the bank, thereby increasing the probability of bankruptcy. Marcus (1984) also found that deregulation in the banking industry, along with a system of deposit insurance, facilitated competition that eroded the franchise value of the bank.

To protect this franchise value, banks usually undertake high-risk strategies that eventually may lead to bankruptcy. For instance, Hellmann, Murdock, and Stiglitz (2000) showed that the liberalization of both the US and Japanese banking sectors had increased competition to such an extent it could be held accountable for subsequent bank failures in both countries. Besanko and Thakor (1993) also showed that excessive competition could induce banks to take excessive risk, such that banks could generate informational rents by having a long-term relationship with the borrowers and that banks would in general not wish to break this relationship. However, if there were more banks (that is, more competition), borrowers would readily shift their banking operations to other banks. 
Competition on the deposit side may also lead to fragility in that this would increase the deposit rate, thereby lowering bank margins. Supporting this view, Marquez (2002) argued that increased competition in the banking industry would lead to inefficiency, with incumbent banks having an informational advantage over smaller banks. Repullo (2004) also supported the competition-fragility view by suggesting that in a highly competitive market, competition would erode the franchise value of banks, and that a gambling equilibrium would arise such that banks as a whole would take on excessive risk. Conversely, in a less-competitive (oligopolistic) market, banks would be more stable and take on less risk. Elsewhere, Matutes and Vives (1996) showed that market power lowered the probability of bank default.

However, several theoretical studies have argued that competition in the banking sector would not necessarily lead to excessive risk taking or financial fragility. While banks could certainly obtain higher rents in a more concentrated market, these banks would also have the ability to charge higher interest rates for borrowers, such that to meet the higher interest rate criteria, borrowers would need to invest in risky projects. In turn, this would increase the default probability for the bank on the asset side, implying that less competition would lead to banking sector instability (Boyd and De Nicolo, 2005). Furthermore, banking systems that consist of a few larger banks (or a highly concentrated banking system) may induce risk-taking behavior by larger banks because of the doctrine of "too-big-to-fail." During banking crises, governments will usually rescue big banks, thereby generating a moral hazard problem (Kane, 2000). Supporting this 'competition-stability' hypothesis, Caminal and Matutes (2002) argued that traditional competition theory disregards the role of banks in reducing asymmetric information problem. If this is sufficiently strong, competition may 
actually be associated with greater solvency, although the relationship between market power and bank solvency is necessarily complex.

\subsection{Empirical Evidence}

Similar to the underlying theoretical arguments, there is no clear consensus in the empirical literature as to whether competition enhances stability or fragility. Certainly, one reason for the mixed results is the differences in the methodologies used to calculate competition and financial stability, combined with the analysis of banks in different countries and periods. In this subsection, we first review the empirical literature that finds that competition enhances fragility in the banking sector and then the empirical evidence supporting the competition-stability hypothesis.

Most studies investigating competition-stability/fragility hypotheses have concentrated on the US banking system. Using data from the 150 largest US bank holding companies, Keeley (1990) found that an increase in competition caused the charter value of banks to decline, which in turn led to an increase in default risk. In another study, Fungáčová and Weill (2013) found evidence for the competitionfragility hypothesis using quarterly data over 2001-07 from the Russian banking sector, concluding that market power, as measured by the Lerner index, was negatively associated with bank failure.

Evidence from cross-country analysis also tends to favor the competition-fragility hypothesis. Yeyati and Micco (2007) examined the relationship between competition (again measured by the Lerner index) and risk (as measured by the Z-score) using a sample of commercial banks from eight Latin American countries over the period 1993-2002. They found that banks in more competitive banking systems enjoyed less stability. In another cross-country analysis, Beck, Demirgüç-Kunt, and Levine (2006) 
concluded that concentrated banking systems were less likely to experience crisis. Using macroeconomic data on 69 countries over the period 1980-97, they found that the negative relationship between concentration and stability held, once conditioned on macroeconomic, financial, and regulatory characteristics. Moreover, they suggested that 'concentration', which is frequently used as a proxy of competition, might not be a suitable measure of competition. Lastly, Berger et al. (2009) argued that the two strands of literature do not necessarily yield opposing predictions regarding bank market power and stability. Using data on nearly 9,000 banks across 23 developed economies, they found that while there was support for the competition-fragility hypothesis, the increase in loan portfolio risk associated with market power was also consistent with the competition-stability hypothesis.

Some empirical evidence also exists supporting the competition-stability hypothesis. According to this hypothesis, more competition (or typically less concentration) increases banking sector stability. For instance, Nicoló et al. (2006) examined the competition-stability hypothesis using two different data sets, one cross-sectional data on US banks and the other bank-year data from 134 nonindustrial countries. Consistent with their theoretical findings (Boyd et al, 2005), they provided empirical evidence that the probability of bank failure is positively and significantly correlated with concentration. In another single country study, Yaldiz and Bazzana (2010) provided evidence supporting the competition-stability' hypothesis for the Turkish banking sector.

A sizeable array of cross-country and regional analysis also provides empirical evidence supporting this hypothesis. Using Panzar and Rosse (1987) H-statistics as a measure of competition, Schaeck, Cihak, and Wolfe (2009) investigated the relationship between systemic crisis and competition across 45 countries, concluding 
that competitive banking systems were less likely to experience systemic crisis. In addition, they cast doubt on the use of concentration as a measure of competition as this captures different aspects of banking systems. Anginer et al. (2014) undertook a very similar study by investigating the relationship between competition and systemic risk. One of the more distinctive points of this analysis was the use of the Merton credit risk model to measure systemic risk instead of an accounting-based model such as the Z-score. Using data for 1,872 banks from 63 countries over the period 19972009, they found that greater competition in the banking system induced banks to diversify risk that made them less susceptible to systemic shocks. Elsewhere, Liu and Wilson (2013) claimed that the relationship between competition and risk depended on the type of bank. By conducting an analysis of the Japanese banking system over the period 2000-09, they found that an increase in competition reduced the risk of city banks, but increased the risk of regional, Tier 2 regional, Shinkin (cooperative regional banks) and cooperative banks.

In a regional setting, $\mathrm{Fu}$, Lin, and Molyneux (2014) examined the influence of competition, concentration, and regulation on individual bank failure in 14 AsiaPacific countries from 2003 to 2010. They measured competition in both structural (the ratio of the total assets of the three-largest banks to total country assets) and nonstructural ways (Lerner index) and measured systemic risk using Merton's distance to default probability and the Z-score. Fu, Lin, and Molyneux (2014) observed that greater concentration in the banking sector increased financial fragility, reduced pricing power, and increased bank risk exposure. In another study of 12 Asian countries, Soedarmono, Machrouh, and Tarazi (2011) and Soedarmono, Machrouh, and Tarazi (2013) found that market power was associated with higher 
insolvency, even though in less competitive markets banks were often better capitalized.

In other work, Jiménez, Lopez, and Saurina (2013) tested the competition-stability hypothesis using data from the Spanish banking sector. According to their findings, there was a nonlinear relationship between competition and stability after controlling for macroeconomic conditions and banks characteristics. This supports the findings of Martinez-Miera and Repullo (2010) that showed that a nonlinear relationship theoretically exists between competition and risk-taking. In contrast to the findings of Jiménez et al. (2013), in another study conducted on European banking using data from 10 countries over the period 2000-08, Liu, Molyneux, and Wilson (2013) found that an inverted U-shaped relationship existed between competition and stability, but that too much or too little competition could impede financial stability. Tabak, Fazio, and Cajueiro (2012) found the complete opposite, showing that competition affected bank risk-taking behavior nonlinearly-however, unlike Liu et al. (2013), that both high and low competition increased financial stability while moderate competition lowered financial stability.

\section{Methodology and Data}

In this section, we first describe the measurement of market power, and then we discuss the proxy of financial stability along with other control variables. We provide a brief explanation of two estimation methods that we use in this study, which are PVAR and two-stage quantile regression.

\subsection{Lerner Index Calculation}

Our calculation of the Lerner index mainly draws on the stochastic frontier estimation approach proposed by Kumbhakar, Baardsen, and Lien (2012) and Coccorese (2014). 
This estimation technique has advantages over more conventional methods, as argued by Kumbhakar et al. (2012). To start with, there could be optimization error by the firm in minimizing total costs. In addition, markups calculated using the Lerner procedure should theoretically be nonnegative; in practice, the conventional approach generates many nonnegative observations (Coccorese, 2014). Measuring the Lerner index using stochastic frontier techniques overcomes these problems.

In brief, the Lerner index measures the ability of a firm to set a price above marginal cost. In other words, it directly measures the market power of an individual firm. Mathematically, we express this as follows:

Lerner $_{i t}=P_{i t-}-M C_{i t} / P_{i t}$

where $P_{i t}$ and $M C_{i t}$ are the price and marginal cost of the output of bank $i$ in year $t$. We calculate the price of output using the ratio of total revenues to total assets following Fungáčová and Weill (2013) and Fiordelisi and Mare (2014). In line with recent studies, we estimate marginal cost using a trans-log cost function comprising one output, $Q_{i t}$ (loans) and three input prices, $W_{h i t}(h=$ deposits, labor and capital), as follows:

$$
\begin{aligned}
L n T C_{i t}=\alpha_{0}+ & \alpha_{1} \operatorname{Ln} Q_{i t}+\sum_{h=1}^{3} \alpha_{h} \ln W_{h i t}+\frac{1}{2} \alpha_{Q Q}\left(\ln Q_{i t}\right)^{2} \\
& +\frac{1}{2} \sum_{h=1}^{3} \sum_{k=1}^{3} \alpha_{h k} \ln W_{h i t} \ln W_{k i t}+\sum_{h=1}^{3} \alpha_{Q h} \operatorname{Ln} Q_{i t} \ln W_{h i t}+\alpha_{E} \ln E_{i t} \\
& +\frac{1}{2} \alpha_{E E}\left(\ln E_{i t}\right)^{2}+\sum_{h=1}^{3} \alpha_{E h} L n E_{i t} \ln W_{h i t}+\alpha_{E Q} \operatorname{Ln} E_{i t} \operatorname{Ln} Q_{i t}+\alpha_{T} T \\
& +\frac{1}{2} \alpha_{T T} T^{2}+\sum_{h=1}^{3} \alpha_{T h} T \ln W_{h i t}+\alpha_{T Q} T \operatorname{Ln} Q_{i t}+\varepsilon_{i t}
\end{aligned}
$$


where $E$ is each bank's total equity, $T$ is a time trend that captures technological change and $\varepsilon$ is the error term. Total equity $(E)$ in this model accounts for the possible use of capital as a source of loan funding. This is in line with the intermediation approach to bank behavior where deposits are an intermediate input for producing loans. To impose the symmetry condition and linear homogeneity restrictions, we divide total cost and the prices of all inputs by the price of labor. As a result, the translog cost function becomes:

$$
\begin{aligned}
\operatorname{Ln}\left(T C_{i t} / W_{3 i t}\right) & \\
= & \alpha_{0}+\alpha_{1} \operatorname{Ln} Q_{i t}+\sum_{h=1}^{2} \alpha_{h}\left(\ln W_{h i t} / W_{3 i t}\right)+\frac{1}{2} \alpha_{Q Q}\left(\ln Q_{i t}\right)^{2} \\
& +\frac{1}{2} \sum_{h=1}^{2} \sum_{k=1}^{2} \alpha_{h k} \ln \left(W_{h i t} / W_{3 i t}\right) \ln \left(W_{k i t} / W_{3 i t}\right)+\sum_{h=1}^{2} \alpha_{Q h} L n Q_{i t} \ln \left(W_{h i t}\right. \\
& \left./ W_{3 i t}\right)+\alpha_{E} \ln E_{i t}+\frac{1}{2} \alpha_{E E}\left(\ln E_{i t}\right)^{2} \\
& +\sum_{h=1}^{2} \alpha_{E h} \operatorname{Ln} E_{i t} \ln \left(W_{h i t} / W_{3 i t}\right)+\alpha_{E Q} \operatorname{Ln} E_{i t} \operatorname{Ln} Q_{i t}+\alpha_{T} T+\frac{1}{2} \alpha_{T T} T^{2} \\
& +\sum_{h=1}^{2} \alpha_{T h} T \ln \left(W_{h i t} / W_{3 i t}\right)+\alpha_{T Q} T \operatorname{Ln} Q_{i t}+\varepsilon_{i t}
\end{aligned}
$$

In this equation, the error term $\varepsilon_{i t}$ is a two-component error term, $\varepsilon_{i t}=v_{i t}+v_{i t}$, where $v_{i t}$ is a two-sided error term representing noise, and $v_{i t}$ is a one-sided disturbance term representing inefficiency. We estimate the equation using maximum likelihood techniques. From Equation 3, we calculate $M C$ as follows: 


$$
M C_{i t}=\frac{T C_{i t}}{Q_{i t}}\left[\tilde{\alpha}_{1}+\tilde{\alpha}_{2} \operatorname{Ln} Q+\sum_{h=1}^{2} \tilde{\mathrm{v}}_{j} \ln W_{h i t}+\grave{\eta}_{2} \mathrm{t}\right]
$$

Once we estimate the marginal cost and compute the price of output, we can calculate the Lerner index for each bank by replacing these values in Equation 1.

\subsection{Financial stability measurement}

We measure the financial stability by using three alternative proxies. Two of the proxies are based on accounting-based information, namely, the Z-score and NPL ratio; and the other proxy is the distance to default (DD), a market-based measurement of financial stability. In the following sections, we briefly describe all three.

\subsubsection{The Z-score}

The Z-score serves extensively in the literature as a proxy of a bank's stability (Ariss, 2010b; Berger et al., 2009; Fiordelisi and Mare, 2014). The Z-score has also been used extensively to measure and compare the stability between conventional and Islamic banks (Bourkhis \& Nabi, 2013; Čihák \& Hesse, 2010; Louati \& Boujelbene, 2015). One of the important reasons for having popularity of the Z-score as a proxy of financial stability is that it can be computed for both listed and unlisted banks, whereas market-based credit risk measurement such as DD can be calculated only for listed banks. The Z-score measures how many standard deviations a bank is from exhausting its capital base. To calculate the Z-score, we use the following:

$Z=(R O A+E / A) / \sigma R O A$ 
where $R O A=$ return on assets, being net profit divided by total assets, $E / A=$ Total equity divided by total assets, and $\sigma R O A=$ standard deviation of ROA over a three-

year period. Generally, a three-year window for the standard deviation of ROA is sufficient to allow for variation in the $\mathrm{Z}$-score. A higher value of $\mathrm{Z}$ indicates the increased solvency of banks and vice versa.

\subsubsection{NPL ratio}

The other accounting-based proxy of stability used in this research is the NPL ratio (Ariss, 2010b; Schaeck and Cihák, 2014). We measure the NPL ratio by dividing the total amount of impaired loans held by the bank by the net amount of loans. A higher NPL ratio indicates the increased probability of bank insolvency.

\subsubsection{Distance-to-default}

The third proxy of stability used in this research is the distance-to-default model, a market-based credit risk measure. Recent literature in banking has adopted DD model as a proxy of stability because it overcomes the many problems accounting-based stability measures face (Anginer et al., 2014; Jokipii and Monnin, 2013; Koutsomanoli-Filippaki and Mamatzakis, 2009). The DD model is calculated using market information following the theory of Merton (1974) and Black and Scholes (1973). The Merton (1974) model assumes that the equity of a firm is equivalent to a call option on the firm's assets, given the equity holders are the residual claimants on the firm's assets after all liabilities have been met. In this model, the strike price of the call option is the book value of the firm's liabilities. If the value of the firm's assets is lower than the strike price, the value of equity is zero. The Merton model has two 
important assumptions. First, the total market value of the firm's underlying assets follows a geometric Brownian motion,

$d V_{A}=\mu V_{A} d t+\sigma_{A} V_{A} d W$

where $V_{A}$ is a firm's assets value, $\mu$ is the expected instantaneous periodic rate of return on assets, $\sigma_{A}$ is the instantaneous standard-deviation of the rate of return on assets, or asset volatility and $d W$ is a standard Weiner process. The second assumption in this model is that the firm has issued a single discount bond maturing in $T$ periods. Under this assumption, the equity of the firm is a call option on the underlying value of the firm's asset with a strike price, denoted by $V_{A}$, equal to the face value of firm's debt, $X$, at time-to-maturity $T$. Using the Black and Scholes (1973) option pricing formula for call options, we express the current market value of equity, $V_{E}$ as:

$V_{E}=V_{A} N\left(d_{1}\right)-X_{e}^{-r T} N\left(d_{2}\right)$

where

$d_{1}=\frac{\ln \left(\frac{V_{A}}{X}\right)+\left(r+0.5 \sigma_{A}^{2}\right) T}{\sigma_{A} \sqrt{ } T}$

and $d_{2}=d_{1}-\sigma_{A} \sqrt{T}$ where $r$ is the risk free rate, $\sigma_{A}$ is the instantaneous standard deviation of the rate of return on the value of assets of banks (asset volatility) and $N$ is the cumulative density function of the standard normal distribution.

In order to calculate the DD, two equations are required. The first is Equation 7, which states that the value of the firm's equity is a function of the value of the firm. The second relates to the volatility of its equity.

$\sigma_{E}=\left(\frac{V_{A}}{E}\right) \frac{\partial E}{\partial V} \sigma_{v}$ 
In the Black-Scholes-Merton model, we can show that $\frac{\partial E}{\partial V}=N\left(d_{1}\right)$, such that under the assumption of Merton's model, the relation between the volatilities of the firm and its equity is

$\sigma_{E}=\left(\frac{V_{A}}{E}\right) N\left(d_{1)} \sigma_{A}\right.$

and the DD and probability of default are:

$D D_{t}=\frac{\ln \left(\frac{V_{A, t}}{X_{t}}\right)+\left(\mu-\frac{1}{2} \sigma_{A}^{2}\right) T}{\sigma_{A} \sqrt{T}}$

$P D=N(-D D)$

where $D D=$ distance-to-default, $P D=$ probability of default, $V_{A}=$ value of assets, $\sigma_{A}=$ volatility of assets, $X_{t}=$ total liabilities, $\mu=$ expected asset return, $T=$ time period, and $N=$ cumulative probability distribution.

This approach has several distinct advantages when compared with other marketbased credit risk indicators such as the ratings of subordinated debt or credit, or accounting-based measures such as the Z-score and NPL ratio. Anginer et al. (2014) argue that using accounting-based credit risk measurement is problematic for investigating the relationship between competition and stability in that it mostly employs accounting information. Hence, there is a probability of spurious regression results and market-based credit risk measurement such DD model overcomes this problem. In addition, we can obtain share price at a high frequency and easily for listed banks. Further, stock prices incorporate investor expectations, thus we can easily consider the DD model as a forward-looking assessment of bank soundness, whereas accounting-based measurements are backward looking. 


\subsection{Estimation Methods}

We use two different sophisticated methodologies to investigate the relationship between competition and stability. These are the PVAR and two-stage quantile regression methods. In the following sections, we briefly discuss these methods.

\subsubsection{PVAR Estimation Technique}

Since seminal work by Sims (1980), VAR has played a significant role in analyzing the dynamic relationships between variables. The VAR model is especially useful when the underlying theory is weak and when the variables are endogenous. The PVAR methodology combines the traditional VAR approach with a panel data approach that allows for unobserved individual heterogeneity. Many recent studies have employed PVAR estimation techniques to analyze the behavior of macroeconomic variables (Grossmann, Love, and Orlov, 2014; Jokipii and Monnin, 2013) between macroeconomic and bank-specific variables (Love and Turk Ariss, 2014) and in banking particularly (Koutsomanoli-Filippaki and Mamatzakis, 2009; Louhichi \& Boujelbene, 2016; Saeed and Izzeldin, 2014)

The PVAR estimation technique is suitable for our analysis for three main reasons. First, both our variables of interest (competition and stability) are endogenous, as argued extensively and persuasively in the extant literature. Importantly, significant competition in the banking market can distort stability, whereas, a stable banking system can invite entrance and hence deliver stiffer competition. Unfortunately, the precise relationship between these variables is complex. Given the VAR model does not require any strong a priori relationship between the variables, it is very appropriate for our purpose. Further, the VAR model treats all variables as part of a multiple time-series endogenous system, which also fits with our requirement in that 
both variables of interest are endogenous. Second, the PVAR model accounts for the individual heterogeneity inherent in panel data, which we can remove by introducing a fixed-effects term in the regression. Finally, we can readily calculate impulse response functions and variance decompositions using the PVAR model to aid understanding.

We employ the PVAR model developed by Love and Zicchino (2006) for our analysis. The model takes the following form:

$Z_{\mathrm{it}}=\mu_{\imath \tau}+\varepsilon_{\imath \tau}+\tau Z_{\imath \tau}-1$

where $Z_{\text {it }}$ is a vector of two random variables (here, competition and financial stability), $\tau$ is an $m \times m$ matrix of coefficients, $\mu$ is a vector of $m$ individual effects and Eit is a multivariate white-noise vector of $\mathrm{m}$ residuals. One of the restrictions imposed in the PVAR is that the underlying structure is identical for each cross-sectional unit. However, in practice, this restriction seldom holds. One way to address this problem is to allow for individual heterogeneity in the levels of the variables by introducing fixed effects, denoted $\mu$ in the model. This is one of the advantages of using PVAR (Love and Turk Ariss, 2014). Because of the dependent variable lags, there would be correlation between the fixed effects and the regressors, which results in biased coefficients. In order to eliminate this problem, we use forward-mean differencing, also known as the Helmert procedure, following Love and Zicchino (2006), which removes only the forward mean. This method preserves the orthogonality between transformed variables and lagged regressors, which allows us to use lagged regressors as instruments and estimate the equation by system GMM (Arellano and Bover, 1995). 
After computing the coefficients of the PVAR, we estimate the impulse response functions (IRF) and the variance decompositions (VDC) using a Cholesky decomposition that identifies the orthogonal shocks in our variables. We use the IRFs to identify the response of one variable to the shock of another variable. Variance decompositions estimate the percentage of variation in one variable explained by the shock to another variable over time. We generate confidence intervals for the orthogonolized IRFs using Monte Carlo simulation and identify the response to one shock at a time while holding other shocks constant. An implicit assumption behind the Cholesky decomposition is that the variables listed earlier in the VAR order affect the other variables contemporaneously, whereas the variables listed later in the VAR order impact those earlier listed variables, only with lag. That is, variables listed earlier are more exogenous. Since our data set is a panel and there is large cross country variation among the countries, to control this effect we include Gross domestic product (GDP) growth rate and log of total asset (LTA) in the equation as control variables. Hence, we have four variables in the equation and based on the exogeneity, we order our variables as follows: GDP, LTA, LERNER, and STABILITY. As the GDP growth rate is a macroeconomic variable, GDP will influence bank size. In the same way, the size of the banks will affect market power and we expect market power to influence the stability of the banks.

\subsubsection{Two-stage Quantile Regression}

Quantile regression, as opposed to least squares estimation, provides robust estimation if the treatment of the program varies across different segment of the population, and was first developed by Koenker and Bassett Jr (1978). As argued by Schaeck and Cihák (2014) and Dima et al. (2014), response from weak banks towards competition may differ from the stable banks. Thus, employing quantile regression 
would give a better predictive ability on the relationship between competition and stability. Since our main variable of interest - Lerner index - is an endogenous variable, it may produce biased result in conventional quantile regression estimates. To overcome this problem, we employ the two-stage quantile regression developed by Amemiya (1982). In the first stage, we regress the Lerner index on the excluded instruments along with other exogenous variables. By following Schaeck and Cihák (2014), we use Financial Freedom Index (FFI) as an instrument of market power. In the second stage, we regress the credit risk variable on the predicted value for the Lerner index and other bank specific and macro-specific variables that may potentially affect the stability. We follow a bootstrapping procedure to calculate the correct standard error in the second stage. Our baseline regression equation is as follows:

Stability $=f($ Competition, Bank controls, Macro Controls $)$

\subsection{Control Variables}

We use both bank specific and macro-economic control variables in our regression Equation 14. Of the bank-specific variables, we use the log of total assets (LTA), noninterest income to total income (NIIGR) as a proxy of diversification, the growth of gross loans $(G G L)$ and the loan to deposit $(L C D)$ ratio. Among the country-specific variables, we use inflation, an economic freedom index $(E F I)$ and a governance index. Table 1 provides definitions of the variables used in the study.

\section{[INSERT TABLE 1 HERE]}

\subsection{Data}

Our initial sample consists of countries that have both Islamic and conventional banks over the period 2000-2012. Our sample varies slightly depending on the proxies of 
stability. Our initial sample includes 16 countries that have both Islamic banks and conventional banks and data are available to calculate the Z-score and the Lerner index. These are Bahrain, Bangladesh, Brunei, Egypt, Indonesia, Jordan, Kuwait, Lebanon, Malaysia, Mauritania, Pakistan, Qatar, Saudi Arabia, Syria, the United Arab Emirates (UAE), and Yemen. Among these countries, Mauritania and Lebanon do not have data for the NPL ratio, and thus excluded when the dependent variable is NPL. Further, as the DD calculation requires stock market data, we exclude five more countries (Brunei, Indonesia, Malaysia, Syria and Yemen) from the analysis when DD is the dependent variable due to the lack of market price data. Our final number of observations for the full sample is 2678,2283 , and 1342 when the stability proxies are the Z-score, NPL ratio and DD score respectively. Data for the bank-specific variables are from the Bankscope database and the macroeconomic data are from the World Bank database and the Heritage Foundation.

\section{Descriptive Statistics}

Table 2 presents summary statistics of the variables. As shown, the overall mean of LI for Islamic banks $(0.23)$ is significantly higher than that for conventional banks (0.14). This result is consistent with the prior literature (Ariss, 2010a; Weill, 2011) concerning the competitive differences between Islamic and conventional banks. Our proxy for stability is significantly higher for conventional banks (66.75) than Islamic banks (55.814). This suggests that Islamic banks are less stable. The overall NPL ratio is $9.917 \%$ for the full sample, whereas the NPL ratios for conventional and Islamic banks are $9.33 \%$ and $8.62 \%$, respectively. This implies that the NPL ratio is

significantly lower for Islamic banks than for conventional banks. The final proxy of stability also shows that Islamic banks have greater stability than conventional banks, 
as the DD score for Islamic banks is significantly higher than that for conventional banks.

Among the bank-specific control variables, we find that the size of the bank is significantly lower for Islamic banks than for conventional banks. This is in line with previous research, as most Islamic banks are relatively new to banking operations in most of the sample countries. Noninterest income to total revenue (NIIGR) - a proxy of diversification - is significantly higher for Islamic banks $(41.36 \%)$ than for conventional banks (35.36\%), implying that Islamic bank business operations are relatively more diversified. The growth of gross loans (GGL) is also significantly higher for Islamic banks than for conventional banks, especially as most Islamic banks have experienced unprecedented growth in most of the sample countries. The loan to deposit ratio (LCD) is also significantly higher for Islamic banks. Among the macroeconomic variables, the average score of the Economic Freedom index (EFI) is 54.96 among the sample countries. The financial freedom index lies between 19.65 and 90 with an average score of 38.2. Average inflation is $6.3 \%$, ranging between $10 \%$ and $53 \%$. Finally, the governance score lies between -1.928 and 0.790 , with an average score of -0.451 .

\section{[INSERT TABLE 2 HERE]}

\section{Empirical Analysis}

\subsection{PVAR Analysis}

In this section, we present the PVAR estimation results followed by the impulse response functions and variance decompositions of competition and financial stability. One of the more important steps in VAR estimation is to select the appropriate lag length. Selecting too many lags will result in the loss of degrees of 
freedom, while too short a lag will fail to capture the model dynamics. We first use the Lagrange multiplier (LM) test for autocorrelation to select the appropriate lag length. The result shows that the appropriate lag length is one. We confirm this with the results of the Schwarz information criteria (SIC).

Table 3 displays the estimated coefficient of the PVAR model with a lag of one for both the endogenous and exogenous variables. As our objective is to investigate the impact of competition on stability, we mainly focus on the association between the LI and the three proxies of stability, being the Z-score, the NPL ratio and the DD. From Panel A, the estimated coefficient shows that the lagged value of market power does not have any significant impact on the Z-score in the full sample or for conventional and Islamic banks. In the Granger causality framework, this means that the LI does not Granger-cause the Z-score in either conventional or Islamic banks. From Panel B, we observe that the LI has a significant negative impact on the NPL ratio in the full sample and for conventional banks. However, it has no significant impact on Islamic banks. Finally, from Panel C we can see that the lagged value of the LI has a positive relationship with DD in the full sample and for conventional and Islamic banks. Unfortunately, it is difficult to overly generalize the results based on these regressions because the different proxies of credit risk provide mixed results. To understand further the relationship between competition and stability, we direct our attention to the impulse response functions and variance decompositions.

\section{[INSERT TABLE 3 HERE]}

\subsection{Impulse Response Functions and Variance Decompositions}

To investigate better the competition-stability hypothesis, we concentrate on the impulse response functions and the variance decompositions derived from the PVAR 
estimation. Figures 1-3 plot the impulse response function of the LI with the Z-score, Figures 4-6 the impulse response function of LI with the NPL ratio, and Figures 7-9 the impulse response function of the LI with the DD score. In all of these figures, we plot the responses of the row variables to a one-standard-deviation shock to the column variables. All figures illustrate the responses for the first six years. The two lines on either side of the impulse response are the $5^{\text {th }}$ and $95^{\text {th }}$ percentile bounds, constructed using Monte Carlo simulations with 500 repetitions. Once again, in line with our main objective, we discuss only the shock of the LI on the stability proxies, as represented by the fourth row and the third column in every graph.

\subsubsection{LI and Z-score}

Figures 1-3 illustrate the impulse response function for all banks, conventional banks, and Islamic banks, respectively. From Figure 1, it appears that the impact of a positive one-standard-deviation shock to the LI index results in an increase in the Z-score of nearly 5 points for all banks. This effect remains positive throughout the period and attains equilibrium in the sixth year. This positive relationship between market power and stability supports the competition-fragility hypothesis. Splitting the sample into Islamic and conventional banks provides very similar results. Figure 2 displays the response of the Z-score in conventional banks from an impulse in the LI. The immediate reaction to the LI is an increase in the Z-score in the first year by nearly 5 points, but declines to zero in the second year and remains at zero thereafter. This suggests a positive, but very short-term, relationship between market power and stability. Figure 3 depicts the impulse response for the Z-score and the LI in Islamic banks, and reveals that the Z-score responds negatively to a one-standard-deviation

shock of the LI in the first year, but a positive thereafter. A comparison of conventional and Islamic banks reveals that the effect of market power on the Z-score 
is more persistent for Islamic than conventional banks. However, the immediate effect of market power on stability is positive for conventional banks, but negative for Islamic banks. The key similarity for both banking systems is that the competitionfragility hypothesis is applicable.

Looking at the variance decomposition of the Z-score and LI in Panel A of Table 4, we can see that the Lerner index explains $0.3 \%, 0.04 \%$ and $7 \%$ variation of the Zscore in all, conventional and Islamic banks, respectively. This indicates that market power better explains the variation in stability in Islamic banks than conventional banks, at least when specifying the Z-score.

[INSERT FIGURE 1 HERE]

[INSERT FIGURE 2 HERE]

\section{[INSERT FIGURE 3 HERE]}

\subsubsection{LI and NPL Ratio}

Figures 4-6 plot the impulse response functions for the NPL ratio and the LI for all, conventional and Islamic banks, respectively. As shown in Figure 4 a positive onestandard-deviation shock to the LI results in a decrease in the NPL ratio by $0.50 \%$ in the first year and a slight decrease in the second year. It then starts to increase, but far from the equilibrium, indicating that the effect of market power on the NPL ratio is long lasting. The impulse response function for conventional banks (Figure 5) demonstrates similar trends. For Islamic banks (Figure 6), while the NPL responds negatively to the shock of the LI similarly to conventional banks, it does not have such a sudden subsequent decrease. Overall, these graphs indicate that the impact of market power on the NPL ratio is negative, which supports the competition-fragility hypothesis. The variance decomposition presented in Table 4 (Panel B), indicates that 
the LI explains $0.7 \%$ of the variation in the NPL ratio for all banks, but only $0.4 \%$ and $0.2 \%$ for conventional and Islamic banks, respectively.

[INSERT FIGURE 4 HERE]

[INSERT FIGURE 5 HERE]

\section{[INSERT FIGURE 6 HERE]}

\subsubsection{LI and DD Score}

Figures 7-9 plot the impulse response functions for the DD and the LI for all, Islamic and conventional banks, respectively. The positive impact of the LI on the DD for all banks is observable from the estimated impulse response function in Figure 7. According to this, the DD at first responds positively, which progressively declines over the remaining years. As for the conventional banks in Figure 8, we discern consistent evidence that a one-standard-deviation shock to the LI results in a slight increase in the DD for the first year and then a sharp decrease from the second year onwards, albeit still positive. For the impulse response function for Islamic banks in Figure 9, we can see that a one standard-deviation shock to the LI does not have any impact in the first year, followed by a slight increase in the second year, but nearly zero by the time of the sixth year. As shown in Table 4 (Panel C), LI (competition) explains approximately $0.09 \%$ of the variation in DD (stability) for all banks. For Islamic banks, LI explains some $11.00 \%$ of the variation in the DD, but only $0.04 \%$ for conventional banks. This indicates that market power has better predictive ability for the stability of Islamic than conventional banks.

[INSERT FIGURE 7 HERE]

[INSERT FIGURE 8 HERE]

[INSERT FIGURE 9 HERE] 


\section{[INSERT TABLE 4 HERE]}

\subsection{Two-Stage Quantile Regression}

\subsubsection{Impact of LI on the Z-score}

Table 5 presents the results on the impact of market power on the Z-score for all, conventional, and Islamic banks, respectively. Columns 1-5 provide the estimation results for all banks; columns 6-10 for conventional banks; and columns 11-15 for Islamic banks. Using quantile regression, we obtain point estimates for the effect of the LI on different stages of stability for both types of banking systems. We can readily note that the LI has a positive relationship with the Z-score and the impact is significant at the $10^{\text {th }}, 50^{\text {th }}$, and $75^{\text {th }}$ quantiles of all banks. The LI coefficient is also significantly larger for the $75^{\text {th }}$ quantile, suggesting that banks in the uppermost quantile of stability (in terms of the Z-score) benefit more from increasing stability than other banks.

For the sample of conventional banks (Columns 6-10), the LI is significant at the $50^{\text {th }}$ and $75^{\text {th }}$ quantiles at the $5 \%$ and $1 \%$ levels, respectively. Once again, the coefficient of market power is highest at the $75^{\text {th }}$ quantile. Conventional banks in the lower and upper quantiles do not demonstrate any significant impact of market power on the Zscore. On the other hand, the LI has a significant impact on stability at the $10^{\text {th }}$ quantile only for Islamic banks, indicating that high-risk Islamic banks are able to reduce their credit risk by gaining more market power. Market power loses its significance towards the upper quantile of the Z-score for Islamic banks. The strident contrast between Islamic and conventional banks is that high-risk Islamic banks benefit in terms of reducing credit risk by gaining more market power, while safer conventional banks are able to increase their stability only by gaining market power through increasing credit risk. 


\section{[INSERT TABLE 5 HERE]}

Figures 10-12 plot the coefficients obtained from the different quantiles for all, conventional, and Islamic banks, respectively. These figures illustrate a one-unit change of in the LI on stability, all else held constant. The vertical axis is the covariate effect and the horizontal line represents the different quantile scale. As reported earlier, while in both all and conventional banks the estimated coefficients increase with the quantile, they decrease for Islamic banks. One notable similarity across all of the bank types is that from the $80^{\text {th }}$ quantile onwards, the coefficient has a decreasing trend, indicating safer banks benefit less in reducing credit risk by gaining market power than riskier banks. Altogether, we have established a positive relationship between market power and stability, thereby supporting the competitionfragility hypothesis.

\section{[INSERT FIGURE 10 HERE]}

\section{[INSERT FIGURE 11 HERE]}

\section{[INSERT FIGURE 12 HERE]}

Among the bank-specific control variables, size has a significant positive impact on the Z-score in the lower quantile but a significant negative impact on the upper quantile of the Z-score. This indicates that riskier banks can increase their stability by

increasing their size. Our proxy for diversification (NIIGR) signifies a significant negative relationship with the Z-score at the lower and median quantiles for both banking systems, while the growth of gross loans (GGL) shows a significant negative impact on the Z-score across all quantiles for all banks, but no significant impact on Islamic banks. The Economic Freedom Index (EFI) displays a significant positive relationship with the Z-score in conventional banks only, indicating that more 
economic freedom helps stabilize the banking sector. Consistent with conventional economic theory, inflation (INF) shows a significant negative relationship with the Zscore for all and conventional banks only. Governance appears to be positively significant for all banks and the upper quantile of Islamic banks, signifying good governance is necessary for achieving better stability in all banking systems.

\subsubsection{Impact of LI on the NPL Ratio}

Table 6 details the quantile regression results for the relationship between the LI and the NPL ratio. Columns 1-5 are the results for all banks, Columns 6-10 for conventional banks, and Columns 11-15 for Islamic banks. As shown, LI has a significant negative impact on the NPL ratio across all quantiles for all banks, implying that an increase in market power significantly lowers the NPL ratio, thus supporting the competition-fragility hypothesis. We obtain a similar result for conventional banks. However, market power has no significant impact on reducing the NPL ratio for Islamic banks in the upper and lower quantiles. In other words, Islamic banks with very low or extremely high NPL ratios obtain no significant benefit in terms of reducing credit risk by gaining market power.

\section{[INSERT TABLE 6 HERE}

To appreciate better the effect of LI on the NPL ratio, we plot its coefficients for the quantiles in Figures 13-15 for all, conventional, and Islamic banks, respectively. In Figure 13, we can see that the effect of the LI on the NPL ratio is consistently negative. We also note that the effect of market power on stability varies a great deal across the different quantiles. Figure 14, which illustrates the effect of the Lerner index on the NPL in different quantiles for conventional banks, indicates similar results. Figure 15 depicts the impact of the Lerner index on the NPL ratio for Islamic banks. Overall, the graphs signify that troubled banks benefit more from an increase 
in market power than comparatively more stable banks. Moreover, conventional banks have a better ability to lower credit risk than Islamic banks in all quantiles in that the coefficients for each quantile of conventional banks are significantly larger than for the corresponding quantiles of Islamic banks.

\section{[INSERT FIGURE 13 HERE]}

\section{[INSERT FIGURE 14 HERE]}

\section{[INSERT FIGURE 15 HERE]}

Among the control variables, size (LTA) has a significant negative impact on the reduction of the NPL ratio in both banking systems. That is, as banks get larger, they have more resources for better screening and monitoring procedures, and more flexibility in rejecting marginal loan applicants, and thus lower their NPL ratios. Noninterest income to total revenue (NIIGR) significantly increases the NPL ratio across all quantiles in conventional banks only. This implies that conventional banks that concentrate on noncore areas of business other than their face greater instability. The growth of gross loans (GGL) has a significant negative impact on the NPL ratio for both conventional and Islamic banks. Elsewhere, the loan to deposit ratio (LCD) has no significant impact on the NPL ratio in either conventional or Islamic banks, while the Economic Freedom Index (EFI) is significant only for conventional banks. Governance score also has a significant negative impact on the NPL ratio, but only for conventional banks.

\subsubsection{Impact of LI on the DD Score}

Table 7 provides the regression results using DD as a proxy of credit risk. As shown in Table 7 (Columns 1-5), the Lerner index has a significant positive impact for all quantiles of the DD score for the all banks, indicating that market power increases 
stability, thus lending support to the competition-fragility hypothesis. The estimated coefficient is largest $(5.01)$ for the $50^{\text {th }}$ quantile and smallest $(2.51)$ for the $10^{\text {th }}$ quantile, implying that banks are in the median $\left(50^{\text {th }}\right.$ quantile $)$ of stability and benefit more by increasing stability through increasing market power.

For conventional banks, the Lerner index positively significantly affects DD at the $1 \%$ level of significance for all quantiles, thus also supporting the competition-fragility hypothesis (Table 7, Columns 6-10). However, the estimated coefficient is largest at the $10^{\text {th }}$ quantile and smallest at the $90^{\text {th }}$ quantile. This indicates that conventional banks with less stability can increase stability by increasing market power. We do not find any significant impact of the Lerner index on the DD for Islamic banks sample except at the $75^{\text {th }}$ quantile.

\section{[INSERT TABLE 7 HERE]}

Figures 16-18 plot the estimated coefficients of the Lerner index for the different quantiles for all, conventional, and Islamic banks. For all banks, the coefficients display an upward trend until the $75^{\text {th }}$ quantile, after which the effect of market power decreases. For conventional banks, the coefficients have an overall decreasing trend, whereas for Islamic banks, the coefficients decrease up until the $30^{\text {th }}$ quantile and then increase up to the $75^{\text {th }}$ quantile. Overall, the estimated coefficients for the Lerner index are larger in conventional than Islamic banks, indicating that increasing market power increases the stability of conventional banks more than Islamic banks.

[INSERT FIGURE 16 HERE]

[INSERT FIGURE 17 HERE]

[INSERT FIGURE 18 HERE] 


\subsection{Comparative Analysis of Conventional and Islamic Banks}

Based on the above discussion, we argue that market power has a significant positive impact on stability for both Islamic and conventional banks. This supports the traditional competition-fragility hypothesis for both banking systems and corresponds with the findings in Ariss (2010b) and Dima, Dincă, and Spulbăr (2014). In addition, the impact of market power on stability is larger for conventional banks than Islamic banks. However, the impact of the Lerner index on any of the credit risk proxies is very weak for Islamic banks, as two out of three do not exhibit any significant correlation with market power across the various quantiles. Importantly, of these credit risk proxies, both the NPL and DD provide more consistent results than the Zscore.

\section{Conclusion}

The competition-stability/fragility nexus is one of the widely investigated hypotheses in the banking literature. One strand of literature argues that excessive competition in the banking industry lowers the franchise value of banks and induces them to have a riskier loan portfolio, and is thus associated with greater instability. The other strand of literature argues that in the absence of competitive forces, banks will charge higher interest rates to borrowers, making loans riskier. Furthermore, the lack of competition often results in a lack of product innovation and efficiency, which may make the industry more fragile. Thus, an 'appropriate' level of competition is required to increase bank stability. Both views enjoy at best mixed theoretical and empirical support in the literature.

The Islamic banking system has experienced unprecedented growth during the last two decades. It has also received special attention from policy makers and regulators 
as a viable alternative banking system. However, contrary to popular opinion, Islamic banks in most countries where they operate face fierce competition from their peers, both Islamic and conventional. Thus, the sustainability of Islamic banks in the longer run is a concern for policymakers as well as practitioners. However, there has been no attempt to date to gauge the effect of competition on stability by comparing Islamic and conventional banks, either in a single country or internationally.

To investigate the competition-stability hypothesis, we selected 16 countries with both Islamic and conventional banks over the period 2000-12. We estimated the market power (lack of competition) using the Lerner index and stability using accounting-based measurements in the form of the Z-score and the NPL ratio, and market-based credit risk measures as DD. We employed PVAR estimation techniques as this method has better predictive ability if the variables considered are likely endogenous. We also derived impulse response functions and undertook variance decompositions to investigate the relationship between competition and stability. As a robustness check, we also employed two-stage quantile regression, as this method is robust to the nonnormality of data and other error term misspecification.

The PVAR estimation method provided interesting results regarding the relationship between competition and stability in both Islamic and conventional banks. First, we do not find a consistent Granger causality effect between competition and stability. Second, our results indicate that a one-standard-deviation shock to the Lerner index results in an increase in stability in the subsequent period for both Islamic and conventional banks, though the magnitude varies greatly depending on the proxy specified. This finding lends support to the competition-fragility hypothesis. Finally, the Lerner index has a short-term effect on both the Z-score and DD and a long-term effect on the NPL ratio. 
Further analysis by using two-stage quantile regression provides some interesting results. First, market power generally increases stability in all banks, irrespective of the proxy used, thus lending support to the competition-fragility hypothesis. Second, the level of significance of market power for stability is stronger for conventional banks than Islamic banks. Third, the magnitude of the effect of the Lerner index is also higher for conventional banks than Islamic banks. Fourth, while we identify a

general positive relationship between market power and stability, the magnitude of the effect on stability significantly varies across both conventional and Islamic banks. Finally, we find that banks in the median quantile have a better ability to turn market power into stability than banks in the lower and upper quantiles.

Our results have a number of policy implications. First, they suggest regulating the level of competition in countries where both Islamic and conventional banks coexist. Second, as the response from weak or riskier banks differs from the response from strong or stable banks significantly in terms of market power, regulators should address this issue in designing appropriate policy for banks. Third, our findings provide evidence that the relationship between market power and stability is nearly identical for Islamic and conventional banks, suggesting a uniform stabilityenhancing regulation and competition policy can sfor both banking systems.

\section{References}

Abedifar, P., Molyneux, P., \& Tarazi, A. (2013). Risk in Islamic Banking. Review of Finance. doi: 10.1093/rof/rfs041

Amemiya, T. (1982). Two stage least absolute deviations estimators. Econometrica: Journal of the Econometric Society, 689-711. 
Anginer, D., Demirguc-Kunt, A., \& Zhu, M. (2014). How does competition affect bank systemic risk? Journal of Financial Intermediation, 23(1), 1-26.

Arellano, M., \& Bover, O. (1995). Another look at the instrumental variable estimation of error-components models. Journal of econometrics, 68(1), 2951.

Ariss, R. T. (2010a). Competitive conditions in Islamic and conventional banking: A global perspective. Review of Financial Economics, 19(3), 101-108.

Ariss, R. T. (2010b). On the implications of market power in banking: Evidence from developing countries. Journal of Banking \& Finance, 34(4), 765-775.

Banker, T. (2013). Top Islamic Financial Institutions. The Banker, 2014.

Beck, Demirgüç-Kunt, A., \& Merrouche, O. (2013). Islamic vs. conventional banking: Business model, efficiency and stability. Journal of Banking \& Finance, 37(2), 433-447.

Beck, T., Demirgüç-Kunt, A., \& Levine, R. (2006). Bank concentration, competition, and crises: First results. Journal of Banking \& Finance, 30(5), 1581-1603.

Berger, A. N., Klapper, L. F., \& Turk-Ariss, R. (2009). Bank competition and financial stability. Journal of Financial Services Research, 35(2), 99-118.

Besanko, D., \& Thakor, A. V. (1993). Relationship banking, deposit insurance and bank portfolio choice: EconWPA.

Black, F., \& Scholes, M. (1973). The pricing of options and corporate liabilities. The journal of political economy, 637-654. 
Bourkhis, K., \& Nabi, M. S. (2013). Islamic and conventional banks' soundness during the 2007-2008 financial crisis. Review of Financial Economics, 22(2), $68-77$.

Boyd, J. H., \& De Nicolo, G. (2005). The theory of bank risk taking and competition revisited. The Journal of Finance, 60(3), 1329-1343.

Caminal, R., \& Matutes, C. (2002). Can competition in the credit market be excessive?

Carletti, E. (2008). Competition and regulation in banking. Handbook of Financial Intermediation and Banking, Elsevier, 449-482.

Čihák, M., \& Hesse, H. (2010). Islamic banks and financial stability: An empirical analysis. Journal of Financial Services Research, 38(2), 95-113.

Coccorese, P. (2014). Estimating the Lerner index for the banking industry: a stochastic frontier approach. Applied Financial Economics, 24(2), 73-88.

Dima, B., Dincă, M. S., \& Spulbăr, C. (2014). Financial nexus: Efficiency and soundness in banking and capital markets. Journal of International Money and Finance, 47, 100-124.

Fiordelisi, F., \& Mare, D. S. (2014). Competition and financial stability in European cooperative banks. Journal of International Money and Finance, 45, 1-16.

Fu, X. M., Lin, Y. R., \& Molyneux, P. (2014). Bank competition and financial stability in Asia Pacific. Journal of Banking \& Finance, 38, 64-77.

Fungáčová, Z., \& Weill, L. (2013). Does competition influence bank failures? Economics of Transition, 21(2), 301-322. 
Grossmann, A., Love, I., \& Orlov, A. G. (2014). The Dynamics of Exchange Rate Volatility: A Panel VAR Approach. Journal of International Financial Markets, Institutions and Money.

Hellmann, T. F., Murdock, K. C., \& Stiglitz, J. E. (2000). Liberalization, moral hazard in banking, and prudential regulation: Are capital requirements enough? American Economic Review, 147-165.

Jiménez, G., Lopez, J. A., \& Saurina, J. (2013). How does competition affect bank risk-taking? Journal of Financial Stability, 9(2), 185-195.

Jokipii, T., \& Monnin, P. (2013). The impact of banking sector stability on the real economy. Journal of International Money and Finance, 32, 1-16.

Kane, E. J. (2000). Incentives for banking megamergers: What motives might regulators infer from event-study evidence? Journal of Money, Credit and Banking, 671-701.

Keeley, M. C. (1990). Deposit insurance, risk, and market power in banking. The American economic review, 1183-1200.

Koenker, R., \& Bassett Jr, G. (1978). Regression quantiles. Econometrica: Journal of the Econometric Society, 33-50.

Koutsomanoli-Filippaki, A., \& Mamatzakis, E. (2009). Performance and Merton-type default risk of listed banks in the EU: A panel VAR approach. Journal of Banking \& Finance, 33(11), 2050-2061.

Kumbhakar, S. C., Baardsen, S., \& Lien, G. (2012). A new method for estimating market power with an application to Norwegian sawmilling. Review of Industrial Organization, 40(2), 109-129. 
Liu, H., Molyneux, P., \& Wilson, J. O. (2013). COMPETITION AND STABILITY IN EUROPEAN BANKING: A REGIONAL ANALYSIS*. The Manchester School, 81(2), 176-201.

Liu, H., \& Wilson, J. O. (2013). Competition and risk in Japanese banking. The European Journal of Finance, 19(1), 1-18.

Louati, S., \& Boujelbene, Y. (2015). Banks’ stability-efficiency within dual banking system: a stochastic frontier analysis. International Journal of Islamic and Middle Eastern Finance and Management, 8(4), 472-490.

Louhichi, A., \& Boujelbene, Y. (2016). Credit risk, managerial behaviour and macroeconomic equilibrium within dual banking systems: Interest-free vs. interest-based banking industries. Research in International Business and Finance, 38, 104-121.

Love, I., \& Turk Ariss, R. (2014). Macro-financial linkages in Egypt: A panel analysis of economic shocks and loan portfolio quality. Journal of International Financial Markets, Institutions and Money, 28, 158-181.

Love, I., \& Zicchino, L. (2006). Financial development and dynamic investment behavior: Evidence from panel VAR. The Quarterly Review of Economics and Finance, 46(2), 190-210.

Marcus, A. J. (1984). Deregulation and bank financial policy. Journal of Banking \& Finance, 8(4), 557-565.

Marquez, R. (2002). Competition, adverse selection, and information dispersion in the banking industry. Review of Financial Studies, 15(3), 901-926.

Martinez-Miera, D., \& Repullo, R. (2010). Does competition reduce the risk of bank failure? Review of Financial Studies, 23(10), 3638-3664. 
Matutes, C., \& Vives, X. (1996). Competition for deposits, fragility, and insurance. Journal of Financial Intermediation, 5(2), 184-216.

Merton, R. C. (1974). On the pricing of corporate debt: The risk structure of interest rates*. The Journal of Finance, 29(2), 449-470.

Nicoló, D., De Nicol, G., Jalal, A. M., \& Boyd, J. H. (2006). Bank risk-taking and competition revisited: New theory and new evidence: International Monetary Fund.

Panzar, J. C., \& Rosse, J. N. (1987). Testing for" monopoly" equilibrium. The journal of industrial economics, 443-456.

Repullo, R. (2004). Capital requirements, market power, and risk-taking in banking. Journal of Financial Intermediation, 13(2), 156-182.

Saeed, M., \& Izzeldin, M. (2014). Examining the relationship between default risk and efficiency in Islamic and conventional banks. Journal of Economic Behavior \& Organization.

Schaeck, K., \& Cihák, M. (2014). Competition, efficiency, and stability in banking. Financial Management, 43(1), 215-241.

Schaeck, K., Cihak, M., \& Wolfe, S. (2009). Are competitive banking systems more stable? Journal of Money, Credit and Banking, 41(4), 711-734.

Sims, C. A. (1980). Macroeconomics and reality. Econometrica: Journal of the Econometric Society, 1-48.

Soedarmono, W., Machrouh, F., \& Tarazi, A. (2011). Bank market power, economic growth and financial stability: Evidence from Asian banks. Journal of Asian Economics, 22(6), 460-470. 
Soedarmono, W., Machrouh, F., \& Tarazi, A. (2013). Bank competition, crisis and risk taking: Evidence from emerging markets in Asia. Journal of International Financial Markets, Institutions and Money, 23, 196-221.

Tabak, B. M., Fazio, D. M., \& Cajueiro, D. O. (2012). The relationship between banking market competition and risk-taking: Do size and capitalization matter? Journal of Banking \& Finance, 36(12), 3366-3381.

Weill, L. (2011). Do Islamic Banks Have Greater Market Power\&quest. Comparative Economic Studies, 53(2), 291-306.

Yaldiz, E., \& Bazzana, F. (2010). The effect of market power on bank risk taking in Turkey. Financial Theory and Practice, 34(3), 297-314.

Yeyati, E. L., \& Micco, A. (2007). Concentration and foreign penetration in Latin American banking sectors: Impact on competition and risk. Journal of Banking \& Finance, 31(6), 1633-1647. 
Table 1

This table presents the definition of the variables used in the analysis and their sources

\begin{tabular}{|c|c|c|}
\hline Variable & Description & Source \\
\hline \multicolumn{3}{|l|}{ Z-score components } \\
\hline Return on equity & Net profit/Total asset & Bankscope \\
\hline Leverage & Equity/asset & Bankscope \\
\hline Nonperforming loans & Net impaired loans/Gross loans & Bankscope \\
\hline \multicolumn{3}{|l|}{ Distance to default (DD) components } \\
\hline Volatility of equity $\left(\mathrm{s}_{\mathrm{E}}\right)$ & $\begin{array}{l}\text { Annualized volatility based on daily } \\
\text { share price }\end{array}$ & DataStream \\
\hline Market capitalization & $\begin{array}{l}\text { Share price times number of shares } \\
\text { outstanding }\end{array}$ & DataStream \\
\hline Total liabilities $\left(\mathrm{X}_{\mathrm{t}}\right)$ & $\begin{array}{l}\text { Short-term + half of the long-term } \\
\text { liabilities }\end{array}$ & Bankscope \\
\hline Risk-free rate ${ }^{\circledR}$ & Three-/six-month Treasury rate & $\begin{array}{l}\text { DataStream/Central bank } \\
\text { website/IMF database }\end{array}$ \\
\hline Value of asset $\left(\mathrm{V}_{\mathrm{a}}\right)$ & Market value of asset & Author calculations \\
\hline Volatility of asset $\left(\mathrm{s}_{\mathrm{A}}\right)$ & Volatility of asset & Author calculations \\
\hline Expected return on asset (m) & Expected market return on asset & Author calculations \\
\hline \multicolumn{3}{|l|}{ Lerner index components } \\
\hline Total revenue & Interest + other operating income & Bankscope \\
\hline Total cost & $\begin{array}{l}\text { Interest }+ \text { personnel }+ \text { other } \\
\text { operating expenses }\end{array}$ & Bankscope \\
\hline Total output & Loans + other earning asset & Bankscope \\
\hline Price of deposits & Interest expense/ total deposit & Bankscope \\
\hline Price of labor & Personnel expense/total assets & Bankscope \\
\hline Price of capital & $\begin{array}{l}\text { Other operating expense/ total fixed } \\
\text { assets }\end{array}$ & Bankscope \\
\hline Equity & Total equity & Bankscope \\
\hline \multicolumn{3}{|l|}{ Bank-specific variables } \\
\hline Log of total assets (LTA) & $\begin{array}{l}\text { Natural logarithm of total assets } \\
\text { (USD million) }\end{array}$ & Bankscope \\
\hline Diversification (NIIGR) & $\begin{array}{l}\text { Non-interest income/Total } \\
\text { operating income }\end{array}$ & Bankscope \\
\hline Growth of gross loans (GGL) & Year on year change of total Loan & Bankscope \\
\hline $\begin{array}{l}\text { Loan to deposit ratio (LCD) } \\
\text { Macroeconomic variables }\end{array}$ & Gross loan/ Total deposit & Bankscope \\
\hline Inflation (INF) & $\begin{array}{l}\text { Year on year change of CPI index } \\
\text { Average of six governance }\end{array}$ & World Bank \\
\hline Governance (GOV) & $\begin{array}{l}\text { measures compiled by Kaufmann et } \\
\text { al.(2010) }\end{array}$ & WorldWide Governance Indicators \\
\hline Financial Freedom Index (FFI) & $\begin{array}{l}\text { Index of banking independence, } \\
\text { ranges between } 0 \text { (no } \\
\text { independence) to } 100 \text { (maximum } \\
\text { independence) }\end{array}$ & Heritage Foundation \\
\hline Economic Freedom Index (EFI) & $\begin{array}{l}\text { Index of economic freedom, ranges } \\
\text { between } 0 \text { (no freedom) to } 100 \\
\text { (maximum freedom) }\end{array}$ & Heritage Foundation \\
\hline
\end{tabular}


Table 2

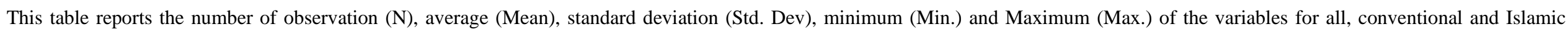

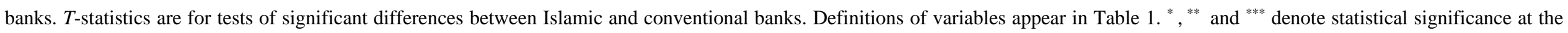
10, 5 and 1 percent levels, respectively.

\begin{tabular}{|c|c|c|c|c|c|c|c|c|c|c|c|c|c|c|c|c|}
\hline \multirow[b]{2}{*}{ Variable } & \multicolumn{5}{|c|}{ All banks } & \multicolumn{5}{|c|}{ Conventional banks } & \multicolumn{5}{|c|}{ Islamic banks } & \multirow[t]{2}{*}{ t-stat } \\
\hline & $\mathrm{N}$ & Mean & Std. Dev. & Min. & Max. & $\mathrm{N}$ & Mean & Std. Dev. & Min. & Max. & $\mathrm{N}$ & Mean & Std. Dev. & Min. & Max. & \\
\hline LI & 2,678 & 0.18 & 0.15 & 0.00 & 0.73 & 2,122 & 0.16 & 0.13 & 0.00 & 0.73 & 556 & 0.25 & 0.20 & 0.00 & 0.73 & $-13.27^{* * *}$ \\
\hline Z-score & 2,678 & 63.71 & 99.04 & -0.96 & 644.17 & 2,122 & 66.76 & 98.04 & -0.96 & 644.17 & 556 & 55.81 & 101.22 & -0.96 & 644.17 & $3.08^{* * * *}$ \\
\hline NPL & 2,283 & 9.20 & 11.40 & 0.10 & 61.60 & 1,901 & 9.33 & 11.14 & 0.11 & 61.60 & 382 & 8.62 & 12.44 & 0.10 & 61.6 & $1.29^{*}$ \\
\hline $\mathrm{DD}$ & 1,342 & 2.24 & 3.31 & -10.74 & 10.01 & 1,151 & 2.17 & 3.26 & -10.74 & 10.01 & 191 & 2.58 & 3.53 & -10.74 & 10.01 & $-1.81^{* *}$ \\
\hline LTA & 2,678 & 7.13 & 2.20 & -3.91 & 15.72 & 2,122 & 7.51 & 1.97 & -2.41 & 15.72 & 556 & 6.24 & 2.44 & -3.91 & 14.17 & $18.07^{* * *}$ \\
\hline NIIGR & 2,678 & 37.09 & 40.22 & -749.63 & 928.27 & 2,122 & 35.36 & 32.50 & -355.02 & 928.27 & 556 & 41.32 & 54.45 & -749.63 & 901.62 & $-4.38^{* * *}$ \\
\hline GGL & 2,678 & 28.73 & 66.54 & -100.00 & 900.69 & 2,122 & 24.5 & 53.27 & -92.88 & 848.10 & 556 & 39.81 & 91.83 & -100.00 & 900.69 & $-6.49^{* * *}$ \\
\hline LCD & 2,678 & 86.16 & 76.23 & 0.08 & 982.50 & 2,122 & 77.47 & 53.37 & 0.77 & 982.50 & 556 & 109.36 & 113.96 & 0.08 & 973.73 & $-12.15^{* * *}$ \\
\hline INF & 2,678 & 0.06 & 0.06 & -0.10 & 0.53 & & & & & & & & & & & \\
\hline GOV & 2,678 & -0.45 & 0.60 & -1.93 & 0.79 & & & & & & & & & & & \\
\hline FFI & 2,678 & 38.20 & 19.65 & 0.00 & 90.00 & & & & & & & & & & & \\
\hline EFI & 2,678 & 54.96 & 16.43 & 0.00 & 77.7 & & & & & & & & & & & \\
\hline
\end{tabular}


Table 3

This table presents the coefficient estimation for the four baseline variables in the PVAR model. ${ }^{*},{ }^{* *}$ and ${ }^{* * *}$ denote statistical significance at the 10,5 and 1 percent levels, respectively.

\begin{tabular}{|c|c|c|c|c|}
\hline \multicolumn{5}{|c|}{ Panel A } \\
\hline Dependent variable : & GDP & LTA & LI & Z-score \\
\hline \multicolumn{5}{|l|}{ All banks } \\
\hline GDP $(t-1)$ & $0.254^{* * *}$ & $0.64^{* * *}$ & 0.037 & 237.033 \\
\hline $\operatorname{LTA}(\mathrm{t}-1)$ & $-0.006^{* * *}$ & $0.843^{* * *}$ & 0.000 & $23.662^{* * *}$ \\
\hline $\mathrm{LI}(\mathrm{t}-1)$ & $0.114^{* * *}$ & 0.029 & $0.474^{* * *}$ & 19.677 \\
\hline Z-score $(t-1)$ & 0.000 & 0.000 & 0.0001 & $0.318^{* * *}$ \\
\hline \multicolumn{5}{|l|}{ Conventional banks } \\
\hline GDP $(t-1)$ & $0.260^{* * *}$ & $0.651^{* * *}$ & -0.036 & 27.746 \\
\hline $\operatorname{LTA}(\mathrm{t}-1)$ & $-0.005^{* * *}$ & $0.849^{* * *}$ & 0.000 & $26.279^{* * *}$ \\
\hline $\mathrm{LI}(\mathrm{t}-1)$ & $0.040^{*}$ & -0.054 & $0.465^{* * *}$ & -14.452 \\
\hline Z-score (t-1) & $0.0001^{* *}$ & $0.000^{*}$ & 0.0001 & $0.288^{* * *}$ \\
\hline \multicolumn{5}{|l|}{ Islamic banks } \\
\hline GDP $(\mathrm{t}-1)$ & $0.223^{* * *}$ & $0.597^{* * *}$ & 0.179 & 888.503 \\
\hline $\operatorname{LTA}(\mathrm{t}-1)$ & $-0.01^{* * *}$ & $0.825^{* * *}$ & -0.005 & 21.6 \\
\hline LI $(\mathrm{t}-1)$ & $0.248^{* * *}$ & 0.024 & $0.433^{* * *}$ & -222.332 \\
\hline Z-score (t-1) & -0.0001 & 0.000 & $0.0001^{* *}$ & $0.389^{*}$ \\
\hline \multicolumn{5}{|c|}{ Panel B } \\
\hline Dependent variable : & GDP & LTA & $\mathrm{LI}$ & NPL \\
\hline \multicolumn{5}{|l|}{ All banks } \\
\hline GDP (t-1) & $0.247^{* * *}$ & $0.680^{* * *}$ & 0.068 & $-13.875^{* * *}$ \\
\hline $\operatorname{LTA}(\mathrm{t}-1)$ & -0.004 & $0.849^{* * *}$ & 0.002 & -0.095 \\
\hline $\mathrm{LI}(\mathrm{t}-1)$ & $0.043^{* * *}$ & $-0.395^{* * *}$ & $0.522^{* * *}$ & $-6.261^{*}$ \\
\hline NPL (t-1) & $-0.002^{*}$ & $-0.004^{* * *}$ & $0.0001^{*}$ & $0.683^{* * *}$ \\
\hline \multicolumn{5}{|l|}{ Conventional banks } \\
\hline GDP (t-1) & $0.263^{* * *}$ & $0.63^{* * *}$ & 0.032 & $-14.966^{* *}$ \\
\hline $\operatorname{LTA}(\mathrm{t}-1)$ & $-0.004^{* *}$ & $0.851^{* * *}$ & 0.002 & -0.187 \\
\hline $\mathrm{LI}(\mathrm{t}-1)$ & 0.009 & -0.232 & $0.534^{* * *}$ & $-8.764^{* *}$ \\
\hline NPL (t-1) & -0.0007 & $-0.003^{* * *}$ & 0.000 & $0.658^{* * *}$ \\
\hline \multicolumn{5}{|l|}{ Islamic banks } \\
\hline GDP $(t-1)$ & $0.241^{* *}$ & $1.019^{* *}$ & 0.134 & $-11.924^{*}$ \\
\hline LTA $(t-1)$ & -0.001 & $0.849^{* * *}$ & -0.003 & 0.086 \\
\hline LI $(\mathrm{t}-1)$ & $0.216^{* * *}$ & $-0.797^{* *}$ & $0.379^{* * *}$ & -1.947 \\
\hline NPL $(t-1)$ & $-0.0002^{*}$ & $-0.013^{* * *}$ & $0.001^{* *}$ & $0.845^{* * *}$ \\
\hline \multicolumn{5}{|c|}{ Panel C } \\
\hline Dependent variable: & GDP & LTA & $\mathrm{LI}$ & $\mathrm{DD}$ \\
\hline \multicolumn{5}{|l|}{ All banks } \\
\hline GDP $(t-1)$ & $0.372^{* * *}$ & 0.109 & -0.008 & $7.166^{*}$ \\
\hline LTA $(\mathrm{t}-1)$ & $-0.006^{* *}$ & $0.776^{* * *}$ & 0.006 & $0.732^{* * *}$ \\
\hline $\mathrm{LI}(\mathrm{t}-1)$ & $0.12^{* * *}$ & $0.411^{*}$ & $0.430^{* * *}$ & 4.904 \\
\hline $\mathrm{DD}(\mathrm{t}-1)$ & $0.002^{* * *}$ & 0.002 & 0.001 & $0.139^{* * *}$ \\
\hline
\end{tabular}




\begin{tabular}{lllll} 
Conventional banks & & & & \\
GDP (t-1) & $0.374^{* * *}$ & $0.34^{*}$ & -0.056 & 6.001 \\
LTA (t-1) & $-0.004^{*}$ & $0.786^{* * *}$ & $0.009^{*}$ & $0.608^{* *}$ \\
LI (t-1) & $0.062^{* *}$ & $0.373^{* *}$ & $0.397^{* * *}$ & $7.39^{*}$ \\
DD (t-1) & $0.001^{* * *}$ & $0.003^{*}$ & 0.000 & $0.13^{* * *}$ \\
Islamic banks & & & & \\
GDP (t-1) & $0.260^{*}$ & $-1.224^{* *}$ & 0.079 & 17.904 \\
LTA (t-1) & -0.006 & $0.713^{* * *}$ & -0.009 & $1.233^{* *}$ \\
LI (t-1) & $0.281^{* * *}$ & 0.304 & $0.424^{* *}$ & 1.179 \\
DD (t-1) & $0.003^{* * *}$ & -0.009 & $0.005^{* * *}$ & $0.23^{* *}$ \\
\hline
\end{tabular}


Table 4

This table presents the variance decomposition for all, conventional and Islamic banks. Each row represents the variance decomposition of the column variable. Each cell shows how much the column variable affects the variance of each row variable.

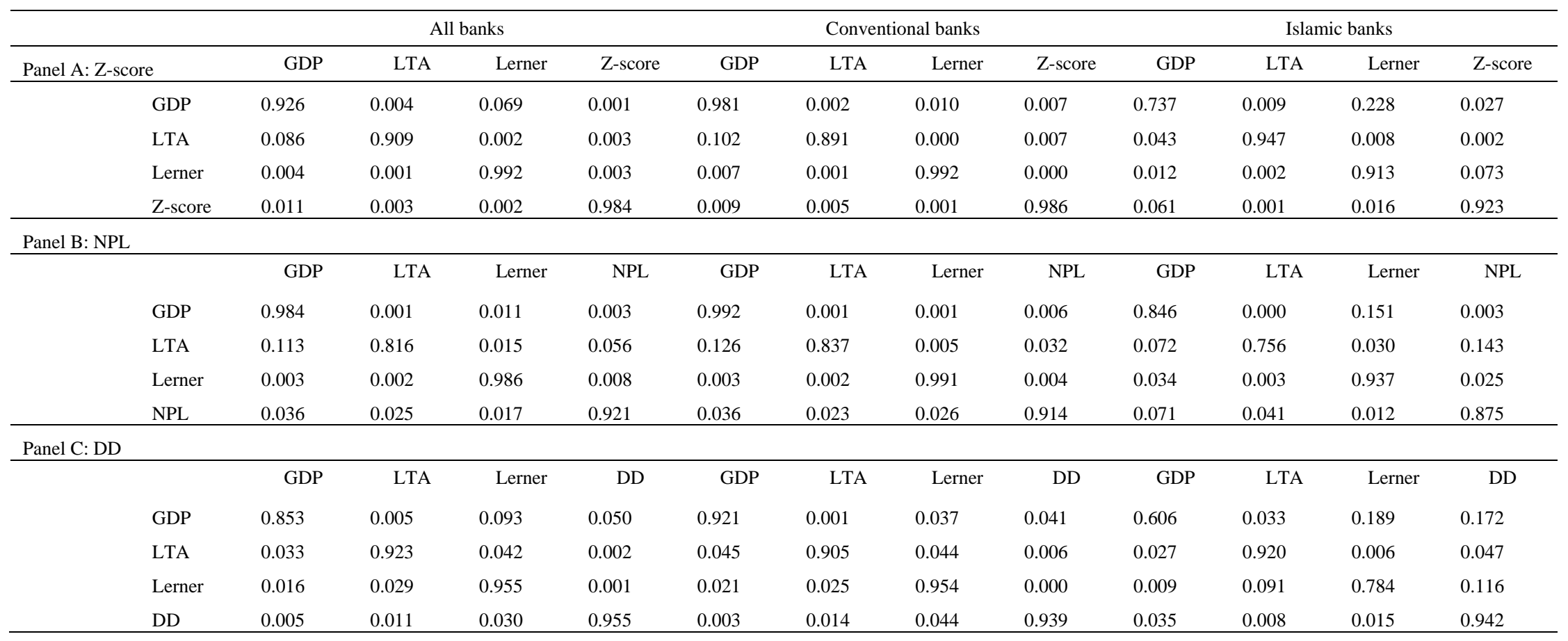


Table 5

This table presents the results of a two-stage quantile regression to examine the impact of competition as measured by the Lerner Index (LI) on stability as proxied by the Z-score. Results reported for all banks and subsamples of conventional and Islamic banks. All variable definitions are in Table 1. T-statistics appear below coefficients. ${ }^{*},{ }^{* *}$ and ${ }^{* * *}$ denote statistical significance at the 10,5 and 1 percent levels, respectively.

\begin{tabular}{|c|c|c|c|c|c|c|c|c|c|c|c|c|c|c|c|}
\hline & \multicolumn{5}{|c|}{ All banks } & \multicolumn{5}{|c|}{ Conventional banks } & \multicolumn{5}{|c|}{ Islamic banks } \\
\hline & (1) & (2) & (3) & (4) & (5) & (6) & (7) & (8) & (9) & $(10)$ & (11) & $(12)$ & (13) & (14) & (15) \\
\hline & 10th & 25th & 50th & 75th & 90th & 10th & 25th & 50th & 75th & 90th & 10th & 25th & 50th & 75th & 90th \\
\hline \multirow[t]{2}{*}{ LERNER } & 5.076 & 6.253 & 17.419 & 37.348 & 24.314 & 1.993 & 8.514 & 19.984 & 69.844 & 49.642 & 10.349 & 2.119 & -11.407 & -37.018 & -98.532 \\
\hline & $1.66^{*}$ & -1.44 & $2.68^{* * *}$ & $1.82^{*}$ & -0.55 & -0.43 & -1.24 & -1.86 & $2.73^{* * *}$ & -0.75 & $1.90^{*}$ & -0.29 & -1.03 & -1.41 & -1.40 \\
\hline \multirow[t]{2}{*}{ LTA } & 0.639 & 0.375 & 0.018 & -1.625 & -8.925 & 0.603 & 0.606 & -0.116 & -0.977 & -6.617 & 0.364 & 0.202 & -0.699 & -2.211 & -9.235 \\
\hline & $3.90^{* * *}$ & -1.56 & -0.05 & $-2.29^{* *}$ & $-5.92^{* * *}$ & $3.34^{* * *}$ & $2.61^{* * *}$ & -0.35 & -1.35 & $-3.91^{* *}$ & -0.73 & -0.37 & -0.84 & -1.14 & $-1.76^{*}$ \\
\hline \multirow[t]{2}{*}{ NIIGR } & -0.044 & -0.056 & -0.066 & -0.120 & -0.028 & -0.062 & -0.069 & -0.082 & -0.133 & -0.034 & -0.035 & -0.023 & -0.014 & 0.133 & 0.291 \\
\hline & $-3.17^{* * * *}$ & $-2.61^{* * *}$ & $-2.48^{* *}$ & $-2.06^{* *}$ & -0.18 & $-3.21^{* * *}$ & $-2.46^{* *}$ & $-2.57^{* *}$ & -1.94 & -0.20 & $-1.63^{*}$ & -0.62 & -0.30 & -0.93 & -0.59 \\
\hline \multirow[t]{2}{*}{ GGL } & -0.017 & -0.036 & -0.036 & -0.075 & -0.186 & -0.020 & -0.019 & -0.030 & -0.066 & -0.155 & -0.011 & -0.021 & -0.003 & -0.028 & -0.178 \\
\hline & $-2.24^{* *}$ & $-2.86^{* * *}$ & $-2.07^{* *}$ & $-2.07^{* *}$ & $-3.80^{* * *}$ & $-2.18^{* *}$ & -1.40 & -1.26 & -1.81 & $-2.98^{* *}$ & -0.83 & -0.90 & -0.08 & -0.67 & -1.14 \\
\hline \multirow[t]{2}{*}{ LCD } & -0.010 & -0.008 & -0.021 & -0.029 & 0.023 & -0.011 & -0.001 & -0.013 & -0.030 & 0.138 & -0.008 & -0.014 & -0.013 & -0.023 & -0.055 \\
\hline & $-2.62^{* *}$ & -0.90 & $-2.38^{* *}$ & -1.16 & -0.33 & -1.22 & -0.12 & -0.60 & -0.51 & -1.05 & -1.48 & -1.51 & -1.12 & -0.93 & -0.85 \\
\hline \multirow[t]{2}{*}{ EFI } & 0.018 & -0.018 & -0.139 & 0.024 & -0.527 & 0.067 & 0.503 & 0.855 & 1.972 & 3.506 & 0.036 & -0.098 & -0.321 & -0.417 & -1.373 \\
\hline & -0.37 & -0.23 & -1.32 & -0.11 & -0.86 & -0.42 & $3.17^{* * *}$ & $2.93^{* * *}$ & $3.46^{* * *}$ & -1.96 & $0.37^{*}$ & -0.77 & $-1.70^{*}$ & -0.94 & -1.19 \\
\hline \multirow[t]{2}{*}{ INF } & -35.420 & -50.647 & -73.660 & -90.338 & -131.123 & -46.114 & -53.535 & -68.003 & -95.167 & -138.387 & 12.213 & 3.725 & -11.001 & 8.423 & 100.695 \\
\hline & $-6.24^{* * *}$ & $-8.17^{* * *}$ & $-10.74^{* * *}$ & $-3.78^{* * *}$ & $-2.10^{* *}$ & $-6.25^{* * *}$ & $-7.41^{* * *}$ & $-9.28^{* * *}$ & $-4.66^{* * *}$ & $-2.18^{*}$ & -0.69 & -0.21 & -0.40 & -0.15 & -0.54 \\
\hline \multirow[t]{2}{*}{ GOV } & 0.833 & 3.095 & 8.023 & 12.664 & 42.230 & 1.241 & 0.571 & 2.457 & -1.711 & 5.077 & 1.693 & 1.925 & 8.076 & 14.551 & 81.263 \\
\hline & -0.83 & $2.18^{* *}$ & $3.68^{* * *}$ & $2.41^{* *}$ & $2.50^{* *}$ & -0.83 & -0.36 & -0.71 & -0.31 & -0.25 & -0.76 & -0.66 & $2.44^{* * *}$ & -1.43 & $2.09^{* *}$ \\
\hline \multirow[t]{2}{*}{ Constant } & 8.886 & 21.718 & 44.376 & 79.851 & 204.213 & 7.982 & -9.896 & -9.271 & -35.330 & -35.833 & 4.652 & 16.515 & 49.352 & 88.138 & 278.878 \\
\hline & $2.50^{* * *}$ & $3.97^{* * *}$ & $6.09^{* * *}$ & $4.38^{* * *}$ & $4.41^{* * *}$ & -0.83 & -1.01 & -0.55 & -1.14 & -0.38 & -0.72 & $1.65^{*}$ & $4.21^{* * *}$ & $3.25^{* * *}$ & $2.78^{* * *}$ \\
\hline $\mathrm{N}$ & 2678 & 2678 & 2678 & 2678 & 2678 & 2122 & 2122 & 2122 & 2122 & 2122 & 556 & 556 & 556 & 556 & 556 \\
\hline R-squared: & 0.018 & 0.02 & 0.022 & 0.026 & 0.041 & 0.024 & 0.031 & 0.034 & 0.041 & 0.052 & 0.014 & 0.007 & 0.009 & 0.013 & 0.048 \\
\hline
\end{tabular}


Table 6

This table presents the results of a two-stage quantile regression to examine the impact of competition as measured by the Lerner Index (LI) on stability as proxied by the NPL ratio. Results reported for all, conventional, and Islamic banks. All variable definitions are in Table $1 . T$-statistics appear below coefficients. ${ }^{*}{ }^{* *}$ and ${ }^{* * *}$ denote statistical significance at the 10,5 and 1 percent levels, respectively.

\begin{tabular}{|c|c|c|c|c|c|c|c|c|c|c|c|c|c|c|c|}
\hline & \multicolumn{5}{|c|}{ All banks } & \multicolumn{5}{|c|}{ Conventional banks } & \multicolumn{5}{|c|}{ Islamic banks } \\
\hline & (1) & $(2)$ & (3) & (4) & (5) & (6) & (7) & (8) & (9) & (10) & (11) & (12) & (13) & (14) & (15) \\
\hline & 10th & 25th & 50th & 75th & 90th & 10th & 25th & 50th & 75th & 90th & 10th & 25th & 50th & 75th & 90th \\
\hline \multirow[t]{2}{*}{ LERNER } & -1.978 & -2.648 & -5.776 & -15.097 & -22.362 & -2.353 & -3.697 & -6.386 & -18.555 & -25.460 & -0.865 & -2.484 & -5.400 & -12.091 & -17.411 \\
\hline & $-3.28^{* * *}$ & $-4.09^{* * *}$ & $-6.16^{* * *}$ & $-7.76^{* * *}$ & $-3.72^{* * *}$ & $-3.46^{* * *}$ & $-4.92^{* * *}$ & $-5.49^{* * *}$ & $-7.67^{* * *}$ & $-3.57^{* * *}$ & -0.80 & $-2.23^{* *}$ & $-3.24^{* * *}$ & $-3.15^{* * *}$ & -1.29 \\
\hline \multirow[t]{2}{*}{ LTA } & 0.034 & -0.051 & -0.235 & -0.820 & -1.553 & 0.024 & -0.069 & -0.246 & -0.804 & -1.546 & 0.085 & -0.026 & -0.203 & -0.875 & -1.684 \\
\hline & -1.36 & $-2.27^{* *}$ & $-5.91^{* * *}$ & $-9.68^{* * *}$ & $-8.64^{* * *}$ & -0.88 & $-2.63^{* * *}$ & $-5.39^{* * *}$ & $-9.06^{* * *}$ & $-8.38^{* * *}$ & -1.47 & -0.44 & $-1.70^{*}$ & $-3.77^{* * *}$ & $-2.44^{* *}$ \\
\hline \multirow[t]{2}{*}{ NIIGR } & 0.004 & 0.007 & 0.009 & 0.034 & 0.06 & 0.005 & 0.004 & 0.011 & 0.04 & 0.068 & 0.001 & -0.003 & -0.02 & 0.011 & 0.054 \\
\hline & $2.27^{* *}$ & $1.92^{*}$ & -1.03 & $2.26^{* *}$ & $2.90^{* * *}$ & $2.02^{* *}$ & -0.82 & -1.3 & $2.62^{* * *}$ & $2.90^{* * *}$ & -0.06 & -0.32 & -0.98 & -0.23 & -0.68 \\
\hline \multirow[t]{2}{*}{ GGL } & -0.015 & -0.022 & -0.034 & -0.046 & -0.044 & -0.016 & -0.022 & -0.034 & -0.044 & -0.038 & -0.014 & -0.019 & -0.025 & -0.041 & -0.075 \\
\hline & $-6.21^{* * *}$ & $-6.99^{* * *}$ & $-7.76^{* * *}$ & $-5.00^{* * *}$ & $-4.24^{* * *}$ & $-6.03^{* * *}$ & $-5.60^{* * *}$ & $-6.00^{* * *}$ & $-4.10^{* * *}$ & $-3.43^{* * *}$ & $-2.41^{* *}$ & $-3.03^{* * *}$ & $-2.75^{* * *}$ & $-3.09^{* * *}$ & $-3.16^{* * *}$ \\
\hline \multirow[t]{2}{*}{ LCD } & -0.001 & -0.001 & -0.002 & -0.001 & -0.004 & -0.001 & 0.001 & -0.000 & -0.007 & -0.005 & -0.002 & -0.002 & -0.003 & 0.003 & 0.034 \\
\hline & -0.78 & -0.76 & -0.74 & -0.16 & -0.25 & -0.53 & -0.3 & -0.03 & -0.86 & -0.37 & -0.77 & -0.86 & -1.09 & -0.2 & -1.12 \\
\hline \multirow[t]{2}{*}{ EFI } & 0.063 & 0.084 & 0.104 & 0.133 & 0.095 & 0.069 & 0.118 & 0.168 & 0.198 & 0.21 & -0.002 & -0.014 & -0.02 & 0.103 & 0.385 \\
\hline & $3.51^{* * *}$ & $3.79^{* * *}$ & $3.62^{* * *}$ & $1.96^{*}$ & -0.61 & $3.73^{* * *}$ & $4.91^{* * *}$ & $4.47^{* * *}$ & $2.03^{* *}$ & -1.24 & -0.06 & -0.30 & -0.38 & -0.69 & -1.1 \\
\hline \multirow[t]{2}{*}{ INF } & 1.06 & 2.585 & 6.503 & 16.24 & 21.895 & 0.478 & 1.532 & 6.158 & 14.182 & 32.385 & 10.474 & 12.603 & 13.54 & 22.39 & 20.115 \\
\hline & -1.23 & -1.52 & -1.9 & $2.71^{* * *}$ & $2.22^{* *}$ & -0.55 & -0.86 & $1.73^{*}$ & $2.00^{* *}$ & $3.20^{* * *}$ & $2.20^{* *}$ & $3.27^{* * * *}$ & $2.33^{* *}$ & $2.15^{* *}$ & -1.12 \\
\hline \multirow[t]{3}{*}{ GOV } & -0.712 & -1.238 & -2.048 & -2.650 & -2.998 & -0.741 & -1.387 & -2.651 & -3.827 & -3.737 & -0.26 & -0.451 & -0.823 & 0.831 & -2.34 \\
\hline & $-3.97^{* * *}$ & $-5.38^{* * *}$ & $-6.63^{* * *}$ & $-3.83^{* * *}$ & $-1.87^{*}$ & $-3.78^{* * *}$ & $-5.20^{* * *}$ & $-6.66^{* * *}$ & $-4.77^{* * *}$ & $-2.17^{* *}$ & -0.68 & -0.88 & -1.30 & -0.51 & -0.66 \\
\hline & $-2.07^{* *}$ & -1.63 & -0.46 & -1.12 & $2.26^{* *}$ & $-2.13^{* *}$ & $-2.44^{* *}$ & $-1.89^{*}$ & -0.3 & -1.55 & -0.01 & -0.87 & -1.56 & -0.97 & -0.21 \\
\hline \multirow[t]{2}{*}{ Constant } & -0.019 & 2.138 & 4.917 & 8.221 & 6.219 & $-2.322^{* *}$ & $-3.467^{* *}$ & $-4.384^{*}$ & 1.642 & 14.92 & -0.019 & 2.138 & 4.917 & 8.221 & 6.219 \\
\hline & -0.01 & -0.82 & -1.59 & -0.98 & -0.28 & -2.02 & -2.44 & -1.95 & -0.3 & -1.38 & -0.01 & -0.82 & -1.59 & -0.98 & -0.28 \\
\hline $\mathrm{N}$ & 2283 & 2283 & 2283 & 2283 & 2283 & 1901 & 1901 & 1901 & 1901 & 1901 & 382 & 382 & 382 & 382 & 382 \\
\hline R-squared: & 0.031 & 0.037 & 0.054 & 0.088 & 0.112 & 0.031 & 0.039 & 0.057 & 0.096 & 0.119 & 0.059 & 0.057 & 0.062 & 0.085 & 0.145 \\
\hline
\end{tabular}


Table 7

This table presents the results of a two-stage quantile regression to examine the impact of competition as measured by the Lerner Index (LI) on stability as proxied by the distance-to-default (DD). Results reported for all, conventional and Islamic banks. All variable definitions are in Table 1. T-statistics appear below coefficients. ${ }^{*},{ }^{* *}$ and *** denote statistical significance at the 10, 5 and 1 percent levels, respectively.

\begin{tabular}{|c|c|c|c|c|c|c|c|c|c|c|c|c|c|c|c|}
\hline & \multicolumn{5}{|c|}{ All banks } & \multicolumn{5}{|c|}{ Conventional banks } & \multicolumn{5}{|c|}{ Islamic banks } \\
\hline & (1) & $(2)$ & (3) & (4) & (5) & (6) & (7) & (8) & (9) & $(10)$ & $(11)$ & $(12)$ & (13) & (14) & (15) \\
\hline & 10th & 25th & 50th & 75th & 90th & 10th & 25th & 50th & 75th & 90th & 10th & 25th & 50th & 75th & 90th \\
\hline \multirow[t]{2}{*}{ LERNER } & 2.512 & 4.393 & 5.014 & 4.839 & 3.921 & 7.989 & 6.987 & 7.214 & 6.141 & 4.685 & 4.625 & -0.720 & 2.476 & 4.064 & 2.757 \\
\hline & -1.37 & $3.48^{* * *}$ & $4.70^{* * *}$ & $6.37^{* * *}$ & $3.01^{* * *}$ & $3.44^{* * *}$ & $5.33^{* * *}$ & $5.62^{* * *}$ & $5.59^{* * *}$ & $2.96^{* * *}$ & -1.17 & -0.34 & -0.86 & $1.93^{*}$ & -1.32 \\
\hline \multirow[t]{2}{*}{ LTA } & 0.006 & 0.087 & 0.157 & 0.094 & 0.022 & 0.143 & 0.131 & 0.198 & 0.134 & 0.041 & -0.001 & -0.086 & 0.241 & 0.057 & -0.011 \\
\hline & -0.08 & -1.53 & $4.49^{* * *}$ & $2.82^{* * *}$ & -0.41 & $1.73^{*}$ & $2.43^{* *}$ & $5.12^{* * *}$ & $2.82^{* * *}$ & -0.66 & -0.00 & -0.35 & -1.21 & -0.51 & -0.09 \\
\hline \multirow[t]{2}{*}{ NIIGR } & -0.004 & -0.005 & -0.002 & 0.004 & 0.007 & -0.012 & -0.004 & -0.000 & 0.003 & 0.011 & 0.042 & 0.007 & 0.018 & 0.036 & 0.033 \\
\hline & -0.50 & -1.01 & -0.32 & -0.51 & -0.82 & -1.22 & -0.86 & -0.02 & -0.31 & -1.14 & -1.37 & -0.27 & -0.83 & -1.42 & $1.96^{*}$ \\
\hline \multirow[t]{2}{*}{ GGL } & 0.001 & 0.001 & -0.001 & -0.002 & 0.007 & -0.001 & 0.001 & -0.002 & -0.006 & 0.003 & 0.012 & 0.003 & 0.004 & 0.011 & 0.003 \\
\hline & -0.3 & -0.41 & -0.24 & -0.85 & -0.81 & -0.20 & -0.18 & -0.91 & $-2.24^{* *}$ & -0.23 & -1.07 & -0.45 & -0.68 & -0.88 & -0.19 \\
\hline \multirow[t]{2}{*}{ LCD } & 0.005 & 0.001 & 0.001 & -0.001 & 0.005 & 0.005 & 0.001 & -0.001 & -0.001 & -0.004 & 0.008 & 0.004 & 0.003 & 0.025 & 0.013 \\
\hline & -1.21 & -0.53 & -0.45 & -0.13 & -1.01 & -0.71 & -0.31 & -0.16 & -0.28 & -0.63 & -0.82 & -0.53 & -0.41 & -0.02 & -1.41 \\
\hline \multirow[t]{2}{*}{ EFI } & 0.183 & 0.066 & 0.029 & 0.057 & 0.137 & 0.129 & 0.015 & -0.001 & 0.045 & 0.132 & 0.101 & 0.098 & 0.049 & 0.062 & 0.082 \\
\hline & $2.41^{* *}$ & $1.66^{*}$ & -1.06 & $1.95^{*}$ & $3.26^{* * *}$ & $1.77^{*}$ & -0.36 & -0.02 & -1.24 & $2.80^{* * *}$ & -0.61 & -0.81 & -0.51 & -0.69 & -1.08 \\
\hline \multirow[t]{2}{*}{ INF } & -22.210 & -22.439 & -20.277 & -16.834 & -11.257 & -24.777 & -23.385 & -19.231 & -16.328 & -10.176 & -13.318 & -10.038 & -27.639 & -19.067 & -16.624 \\
\hline & $-6.28^{* * *}$ & $-6.96^{* * *}$ & $-8.60^{* * *}$ & $-6.36^{* * *}$ & $-3.66^{* * *}$ & $-5.81^{* * *}$ & $-6.90^{* * *}$ & $-7.97^{* * *}$ & $-5.86^{* * *}$ & $-3.22^{* * *}$ & -1.04 & -1.28 & $-3.07^{* * *}$ & $-2.43^{* *}$ & $-2.16^{* *}$ \\
\hline \multirow[t]{2}{*}{ GOV } & 0.379 & 0.956 & 0.957 & 1.073 & 1.059 & 0.737 & 1.297 & 1.206 & 1.144 & 1.381 & 1.147 & 1.066 & 0.455 & 1.464 & 0.858 \\
\hline & -0.64 & $2.60^{* * *}$ & $3.13^{* * *}$ & $4.19^{* * *}$ & $2.08^{* *}$ & -1.15 & $3.61^{* * *}$ & $3.73^{* * *}$ & $3.77^{* * *}$ & $2.31^{* *}$ & -0.83 & -1.21 & -0.42 & $1.79^{*}$ & -1.21 \\
\hline \multirow[t]{2}{*}{ Constant } & -7.861 & -0.722 & 1.991 & 3.058 & -0.407 & -6.338 & 1.23 & 2.975 & 3.325 & 0.832 & -5.046 & -1.971 & 1.141 & 2.094 & 0.034 \\
\hline & $-1.84^{*}$ & -0.33 & -1.25 & $1.76^{*}$ & -0.16 & $-1.64^{*}$ & -0.57 & $1.70^{*}$ & $1.66^{*}$ & -0.28 & -0.48 & -0.30 & -0.22 & -0.38 & -0.01 \\
\hline $\mathrm{N}$ & 1342 & 1342 & 1342 & 1342 & 1342 & 1151 & 1151 & 1151 & 1151 & 1151 & 191 & 191 & 191 & 191 & 191 \\
\hline R-squared: & 0.19 & 0.147 & 0.144 & 0.136 & 0.146 & 0.225 & 0.167 & 0.154 & 0.136 & 0.148 & 0.139 & 0.109 & 0.131 & 0.145 & 0.195 \\
\hline
\end{tabular}


Figure 1

These graphs present the impulse response functions to shocks, PVAR baseline model with four variables: GDP, Size (log of total assets), Lerner and Z-score for all sample banks. The solid lines plot the impulse responses. The dashed lines are 5\% standard error confidences around the estimate. Errors generated by Monte-Carlo with 500 repetitions.

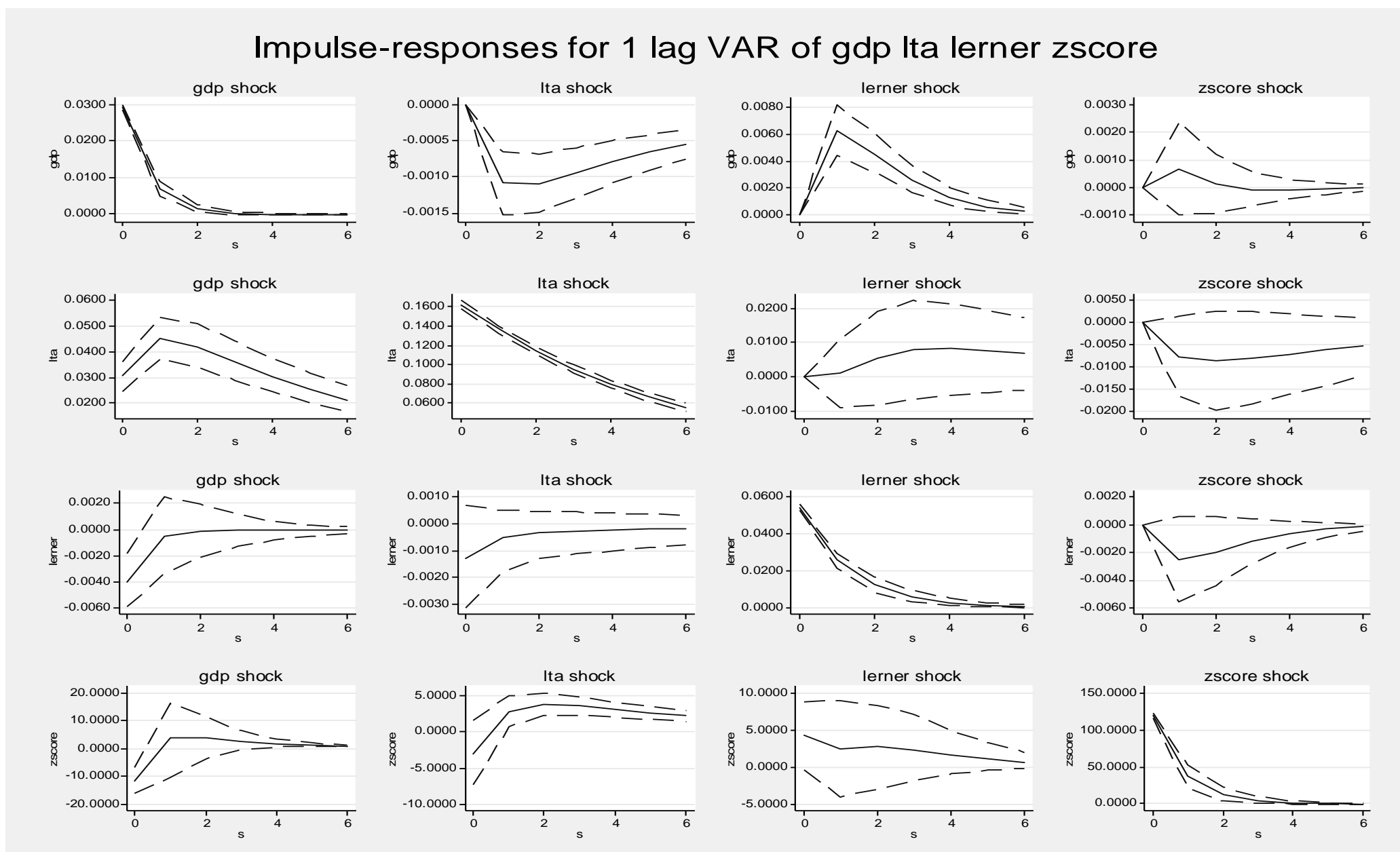

Errors are $5 \%$ on each side generated by Monte-Carlo with 500 reps 
Figure 2

These graphs present the impulse response functions to shocks, PVAR baseline model with four variables: GDP, Size (log of total assets), Lerner and Z-score for conventional banks. The solid lines plot the impulse responses. The dashed lines are $5 \%$ standard error confidences around the estimate. Errors generated by Monte-Carlo with 500 repetitions.

\section{Impulse-responses for 1 lag VAR of gdp Ita lerner zscore}

Sample : if islamic $==0$
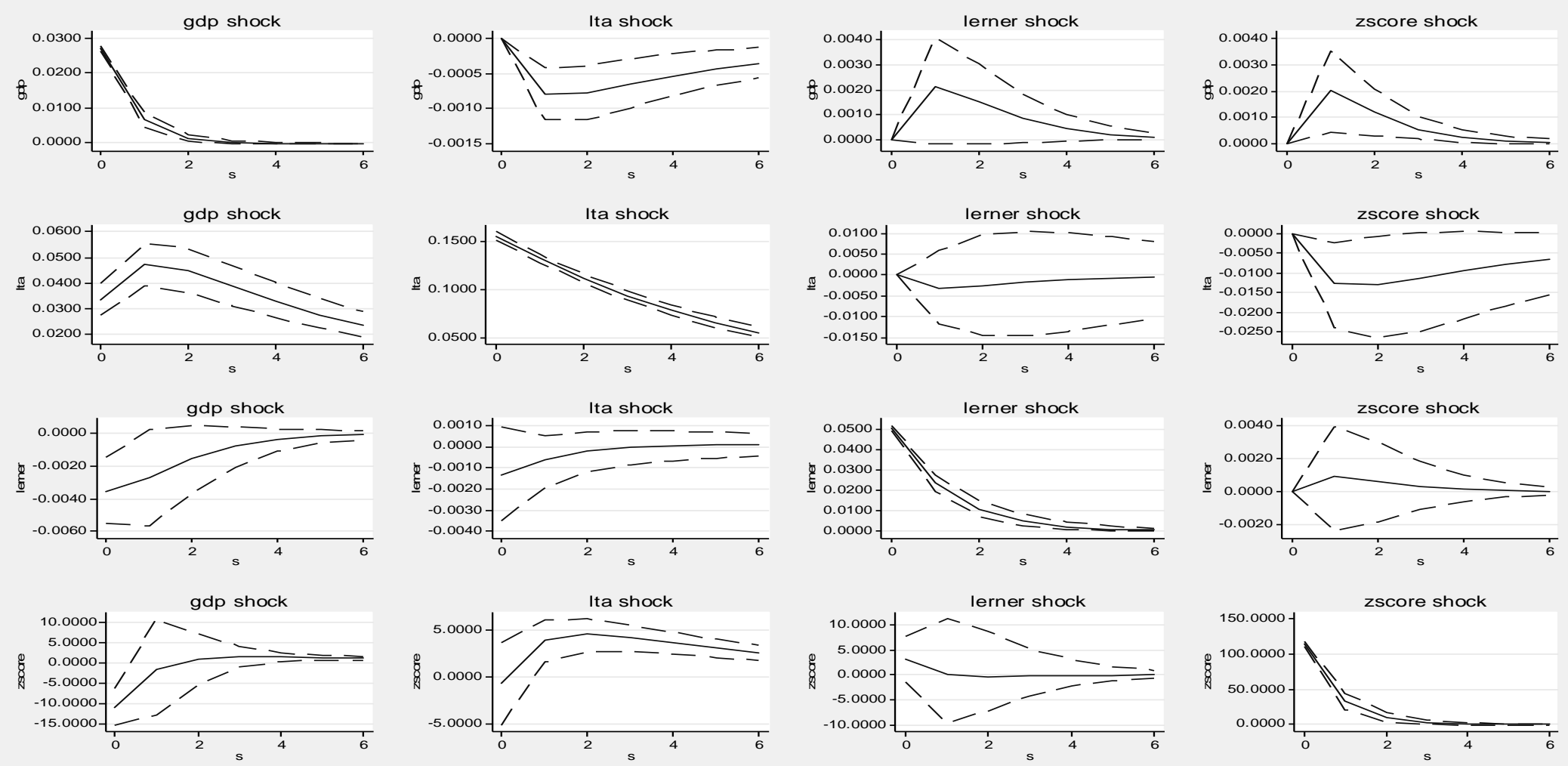

Errors are $5 \%$ on each side generated by Monte-Carlo with 500 reps 
Figure 3

These graphs present the impulse response functions to shocks, PVAR baseline model with four variables: GDP, Size ( log of total assets), Lerner and Z-score for Islamic banks. The solid lines plot the impulse responses. The dashed lines are $5 \%$ standard error confidences around the estimate. Errors generated by Monte-Carlo with 500 repetitions.

\section{Impulse-responses for 1 lag VAR of gdp Ita lerner zscore}

Sample : if islamic $==1$
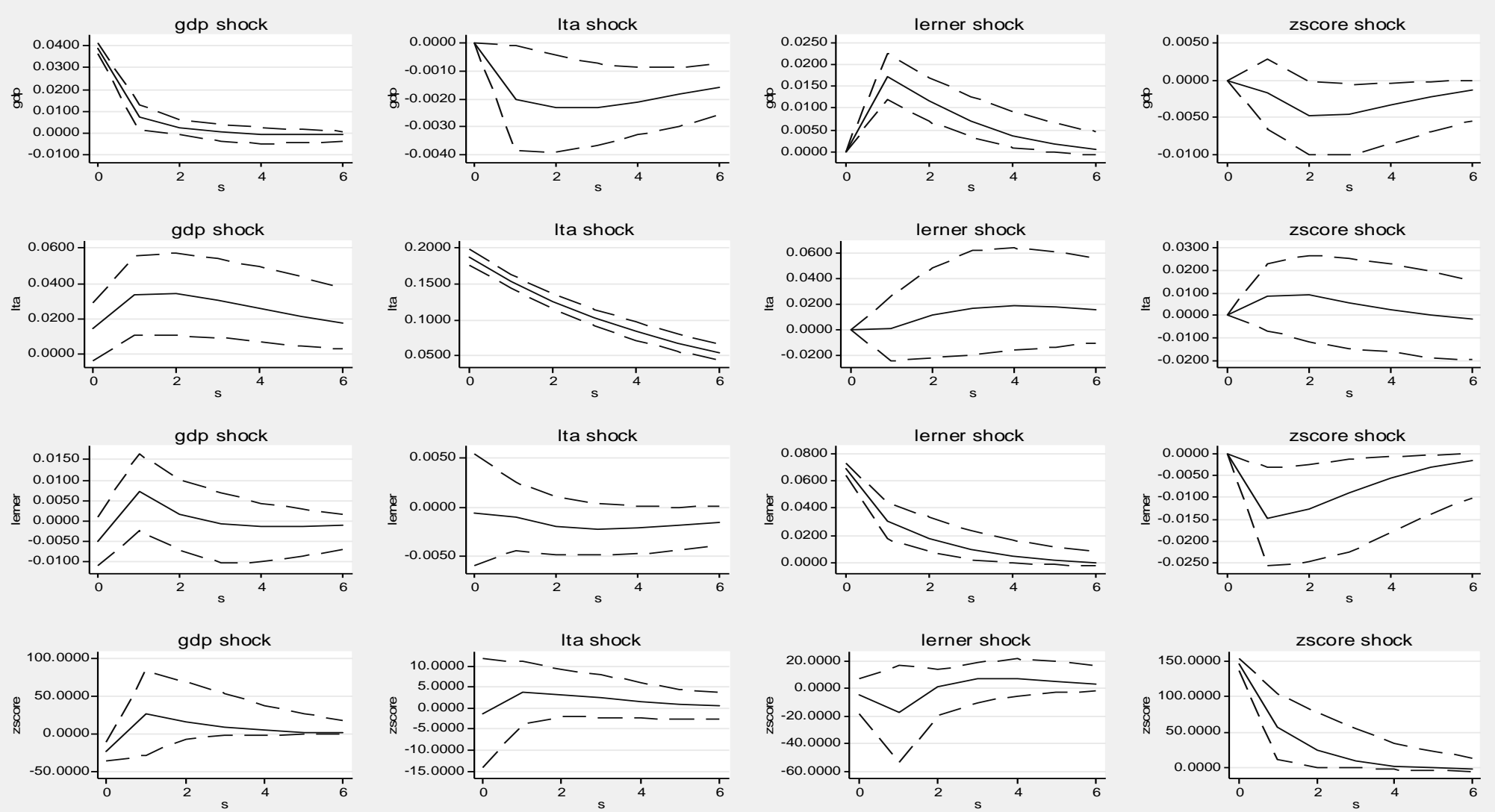

Errors are 5\% on each side generated by Monte-Carlo with 500 reps 
Figure 4

These graphs present the impulse response functions to shocks, PVAR baseline model with four variables: GDP, Size (log of total assets), Lerner and NPL for all sample banks. The solid lines plot the impulse responses. The dashed lines are $5 \%$ standard error confidences around the estimate. Errors generated by Monte-Carlo with 500 repetitions.

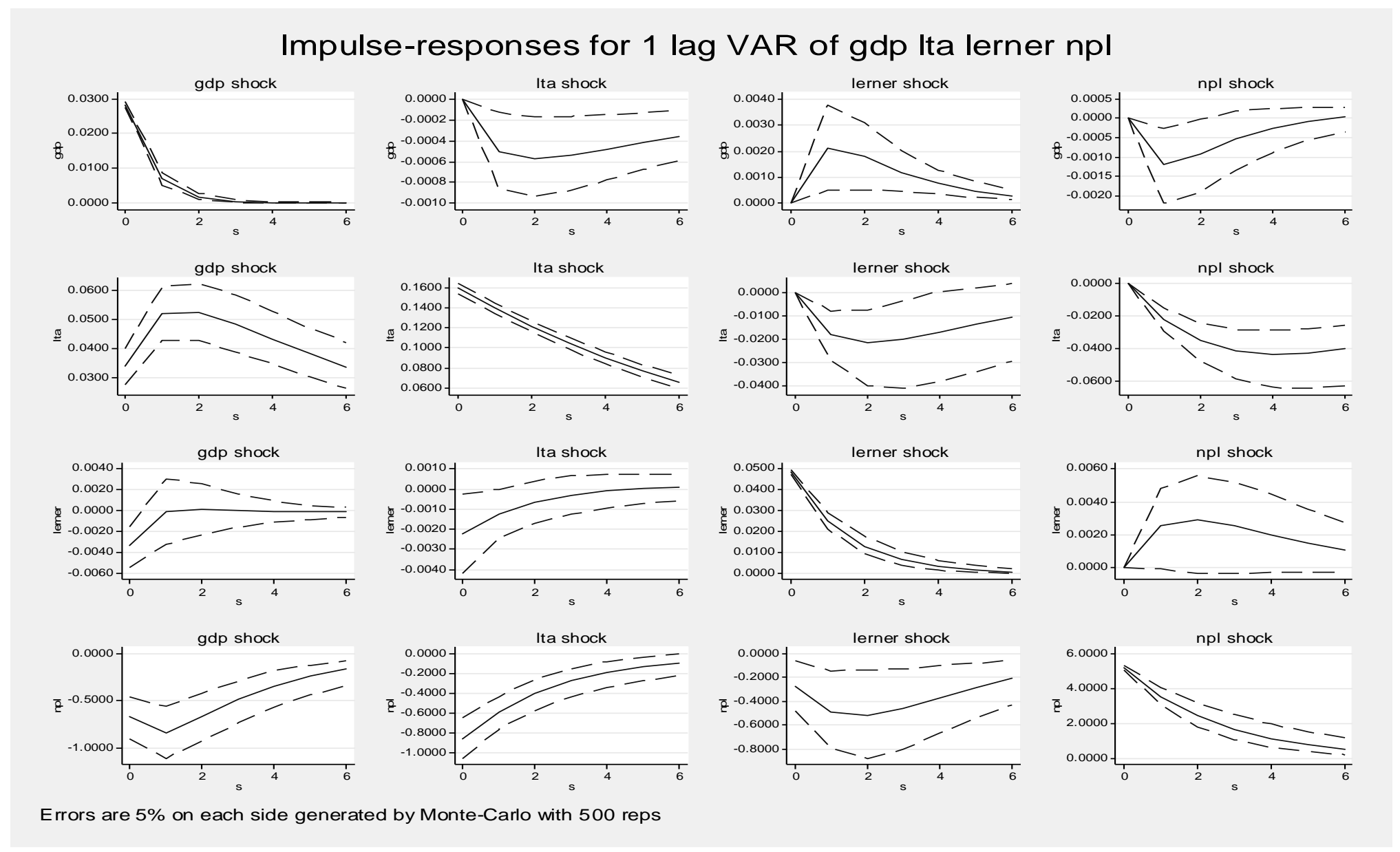


Figure 5

These graphs present the impulse response functions to shocks, PVAR baseline model with four variables: GDP, Size (log of total assets), Lerner and NPL for conventional banks. The solid lines plot the impulse responses. The dashed lines are 5\% standard error confidences around the estimate. Errors generated by Monte-Carlo with 500 repetitions.

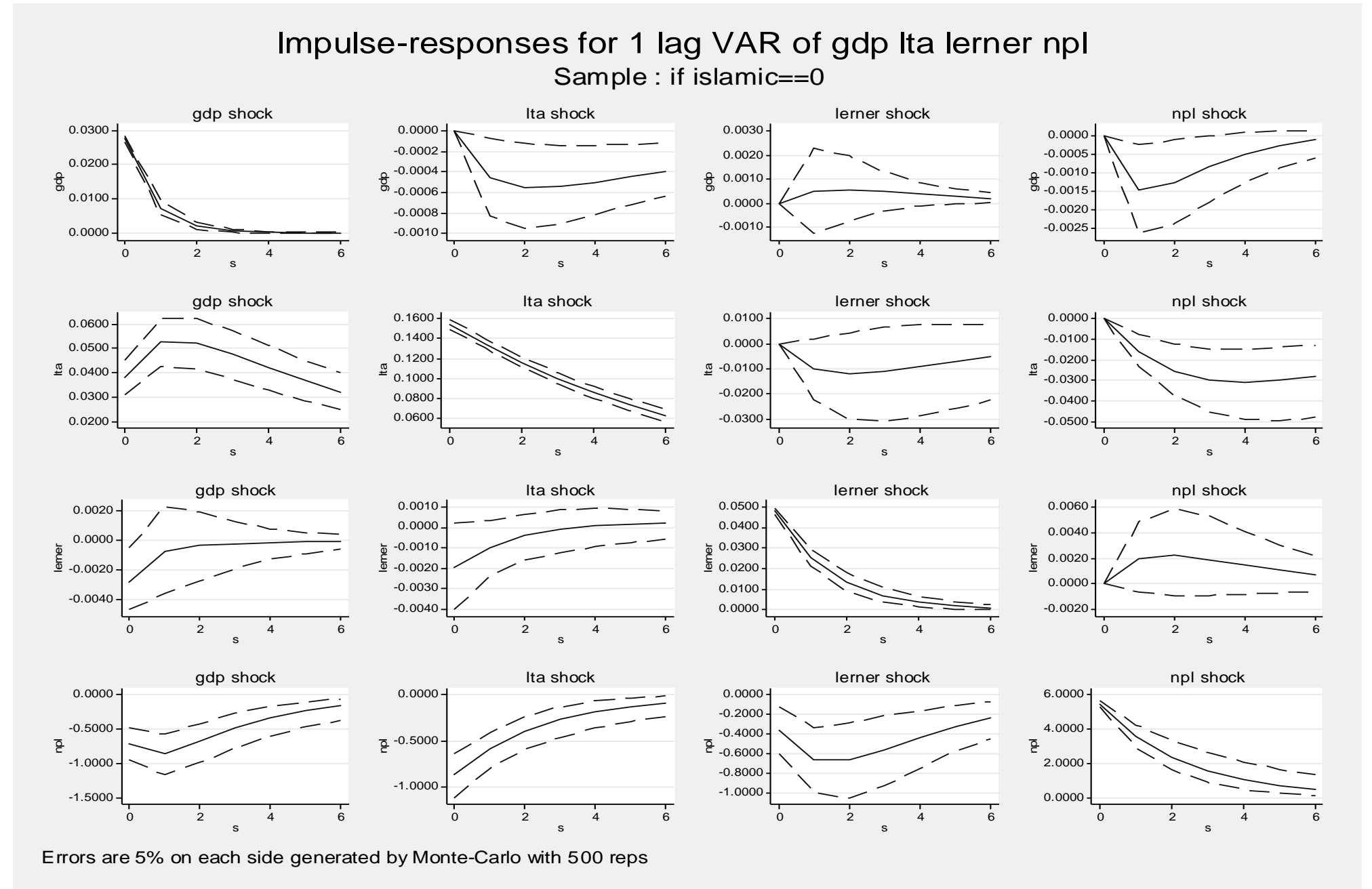


Figure 6

These graphs present the impulse response functions to shocks, PVAR Baseline Model with four variables: GDP, Size (log of total assets), Lerner and NPL for Islamic banks. The solid lines plot the impulse responses. The dashed lines are 5\% standard error confidences around the estimate. Errors generated by Monte-Carlo with 500 repetitions.

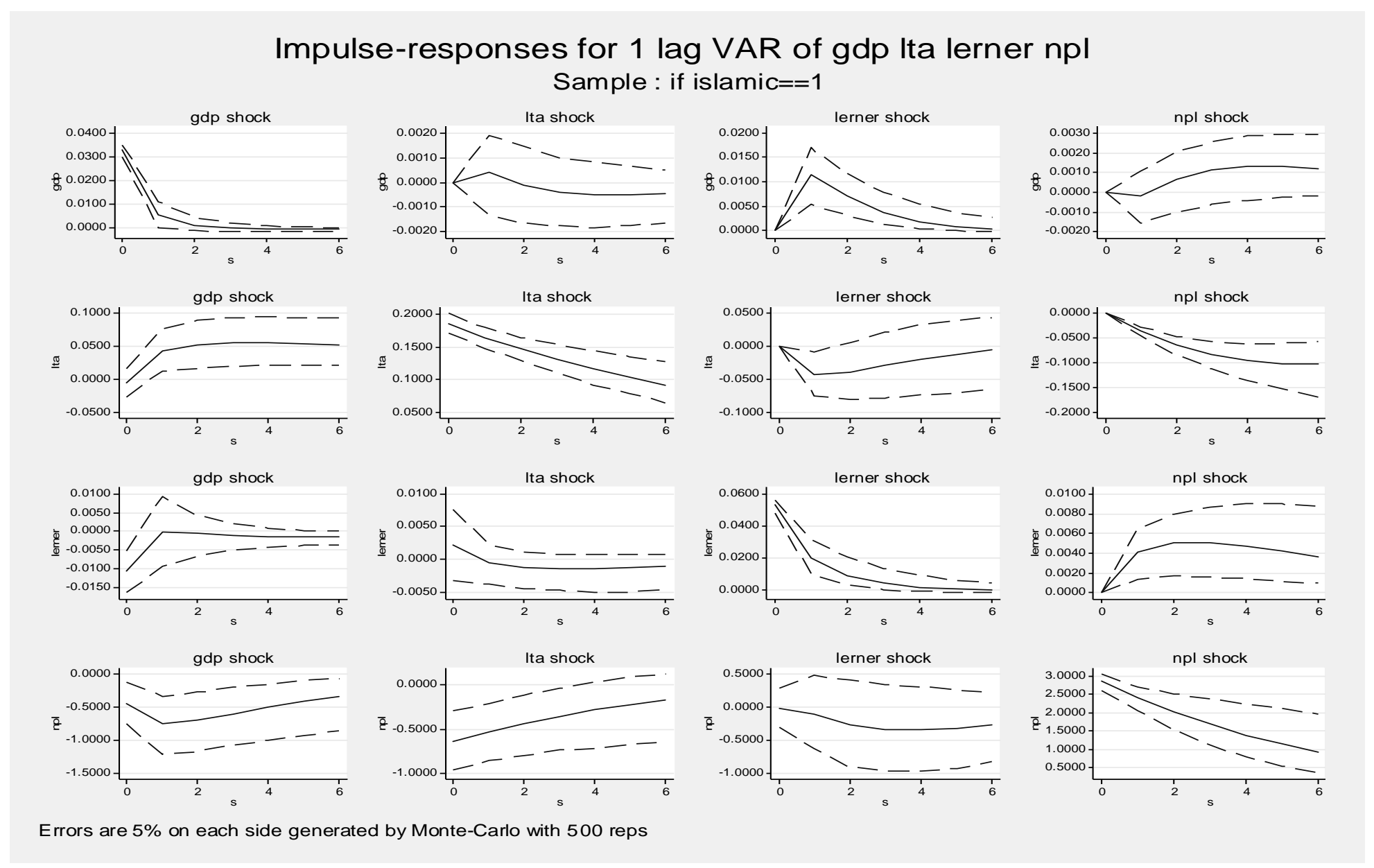




\section{Figure 7}

These graphs present the impulse response functions to shocks, PVAR baseline model with four variables: GDP, Size (log of total assets), Lerner and DD for all sample banks. The solid lines plot the impulse responses. The dashed lines are 5\% standard error confidences around the estimate. Errors generated by Monte-Carlo with 500 repetitions.

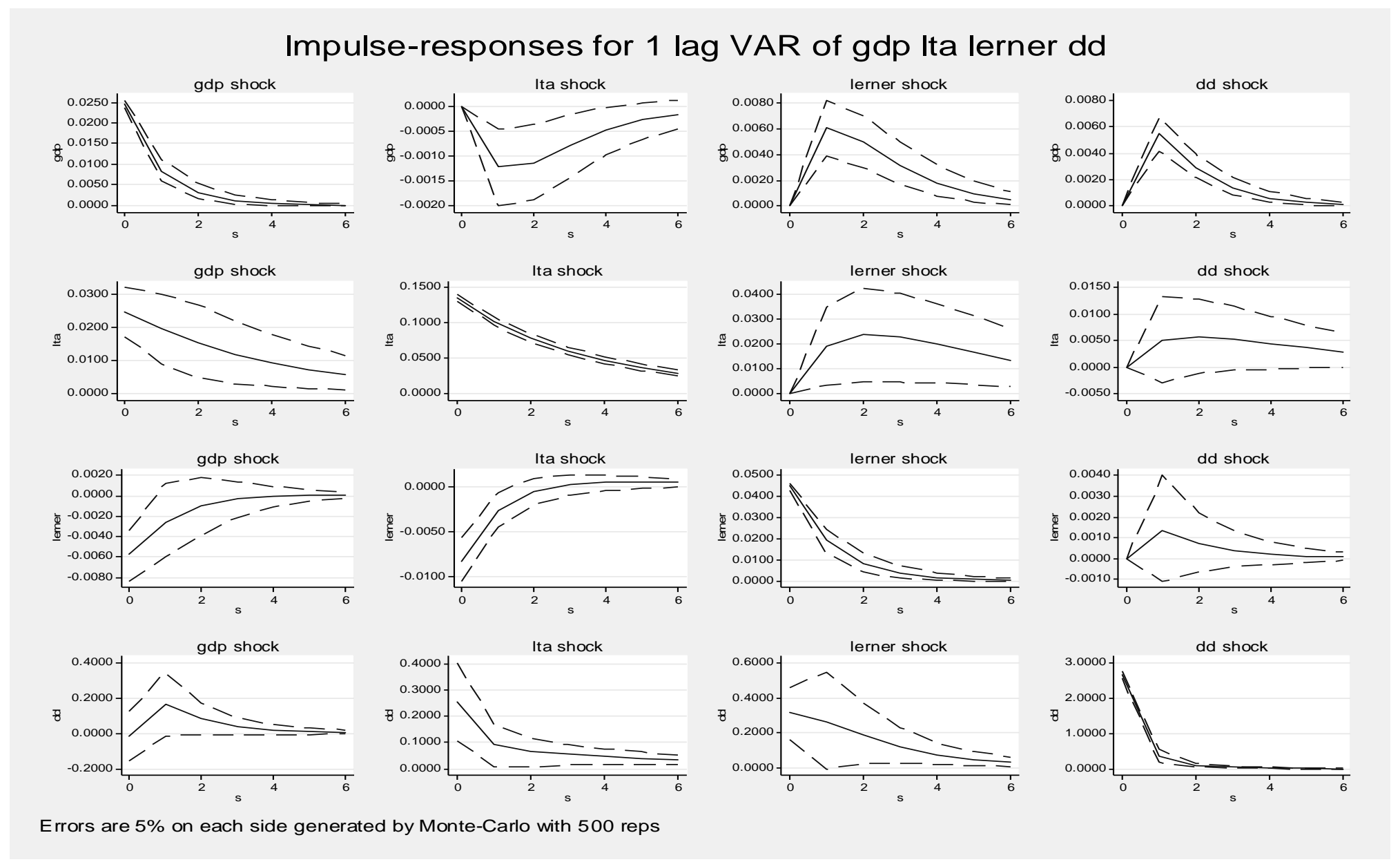


Figure 8

These graphs present the impulse response functions to shocks, PVAR baseline model with four variables: GDP, Size (log of total assets), Lerner and DD for conventional banks. The solid lines plot the impulse responses. The dashed lines are 5\% standard error confidences around the estimate. Errors generated by Monte-Carlo with 500 repetitions.

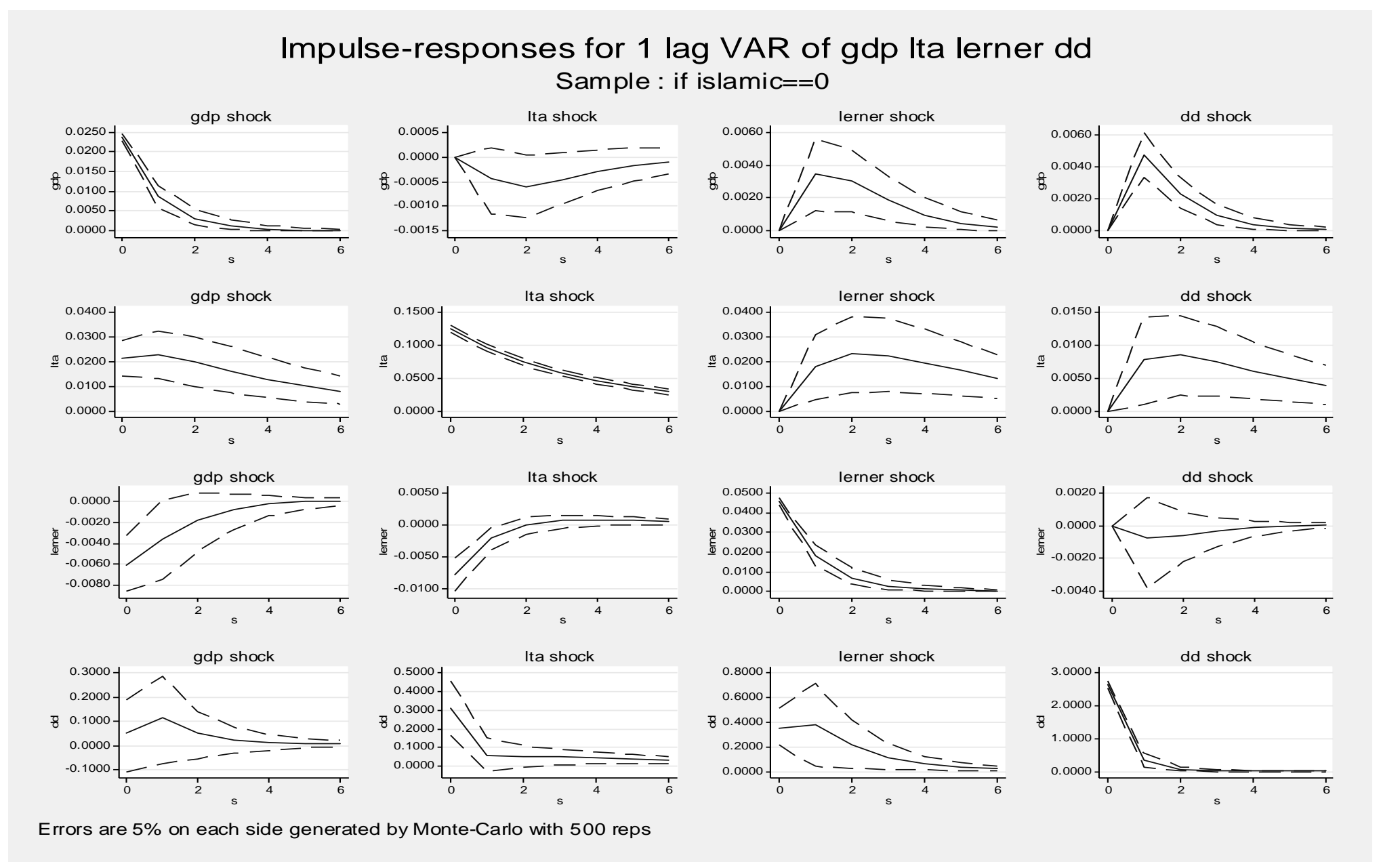




\section{Figure 9}

These graphs present the Impulse response functions to shocks, PVAR baseline model with four variables: GDP, Size (log of total assets), Lerner and DD for Islamic banks. The solid lines plot the impulse responses. The dashed lines are 5\% standard error confidences around the estimate. Errors generated by Monte-Carlo with 500 repetitions.

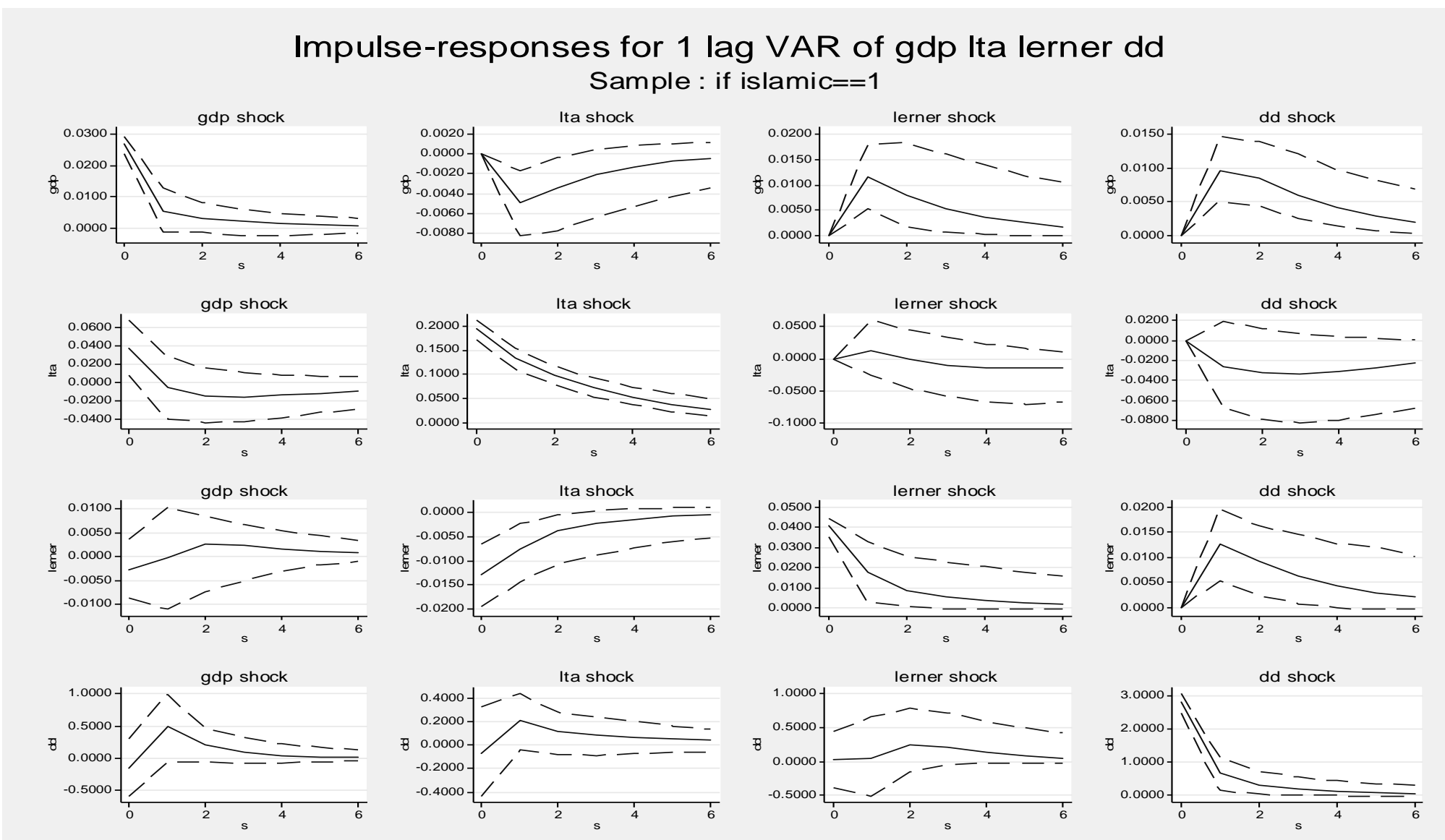

Errors are $5 \%$ on each side generated by Monte-Carlo with 500 reps 
Figure 10

This graph presents the quantile regression estimates of Lerner on Z-score for all banks

\section{Quantile Process Estimates for LERNER (95\% Cl)}

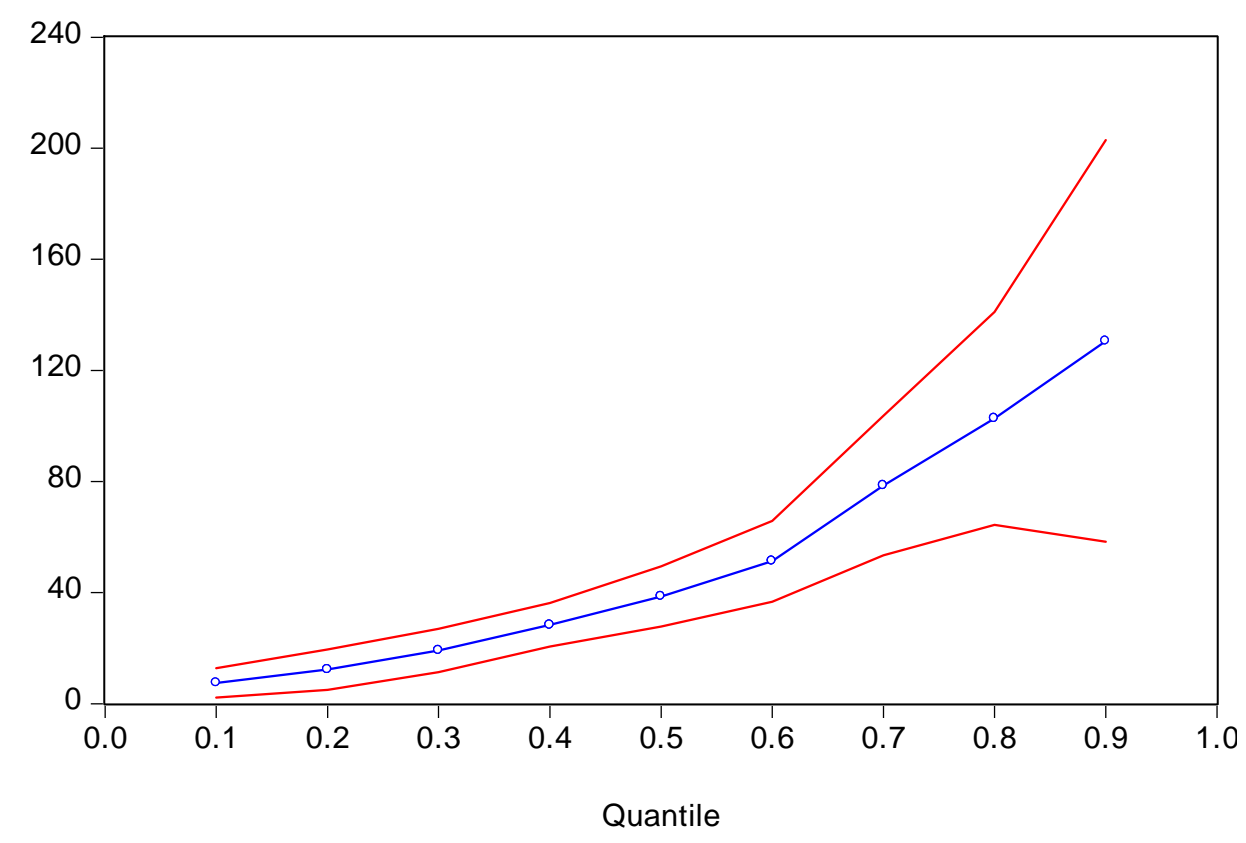

Figure 11

This graph presents the quantile regression estimates of Lerner on Z-score for conventional banks
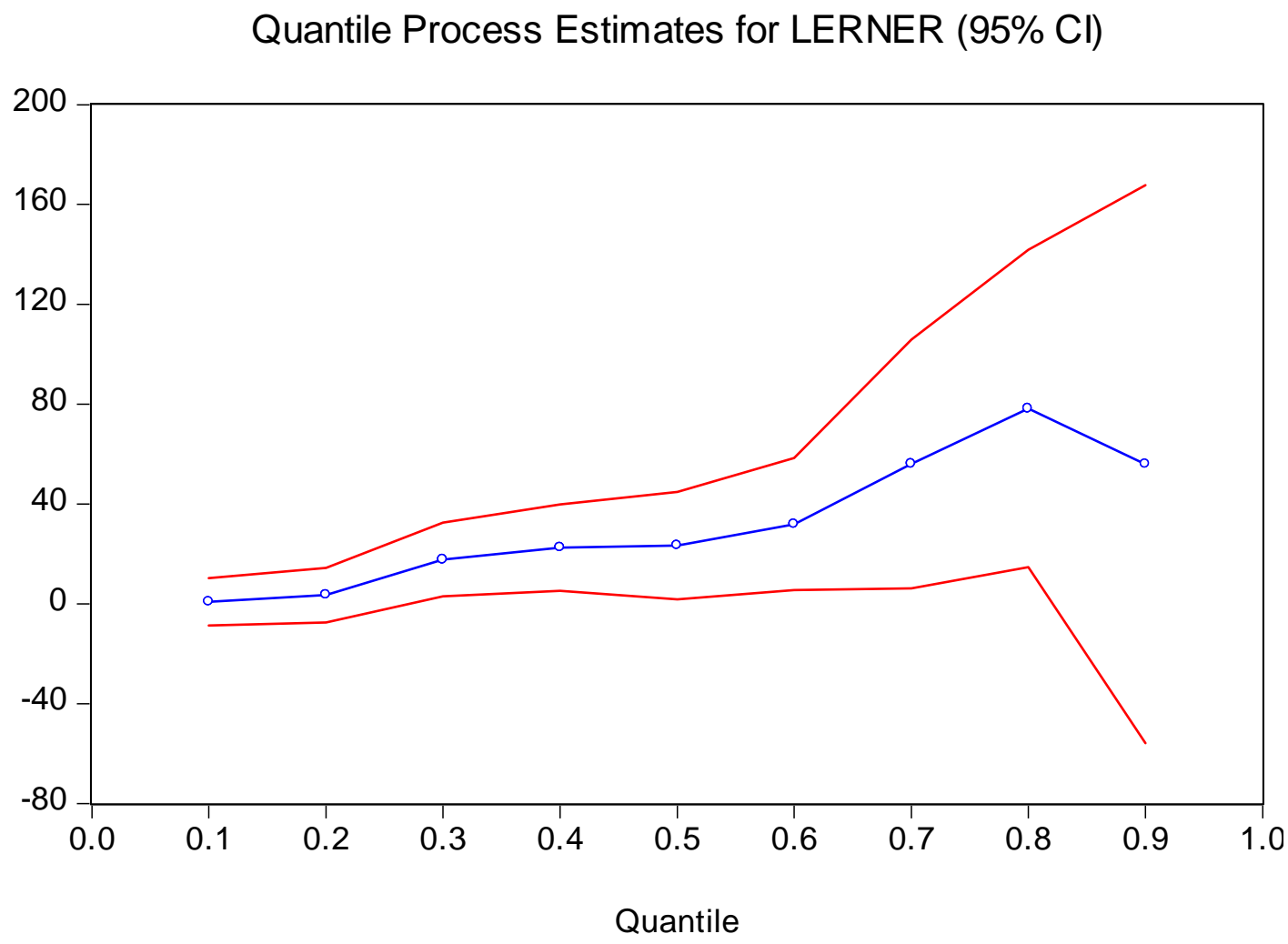
Figure 12

This graph presents the quantile regression estimates of Lerner on Z-score for Islamic banks

\section{Quantile Process Estimates for LERNER (95\% Cl)}

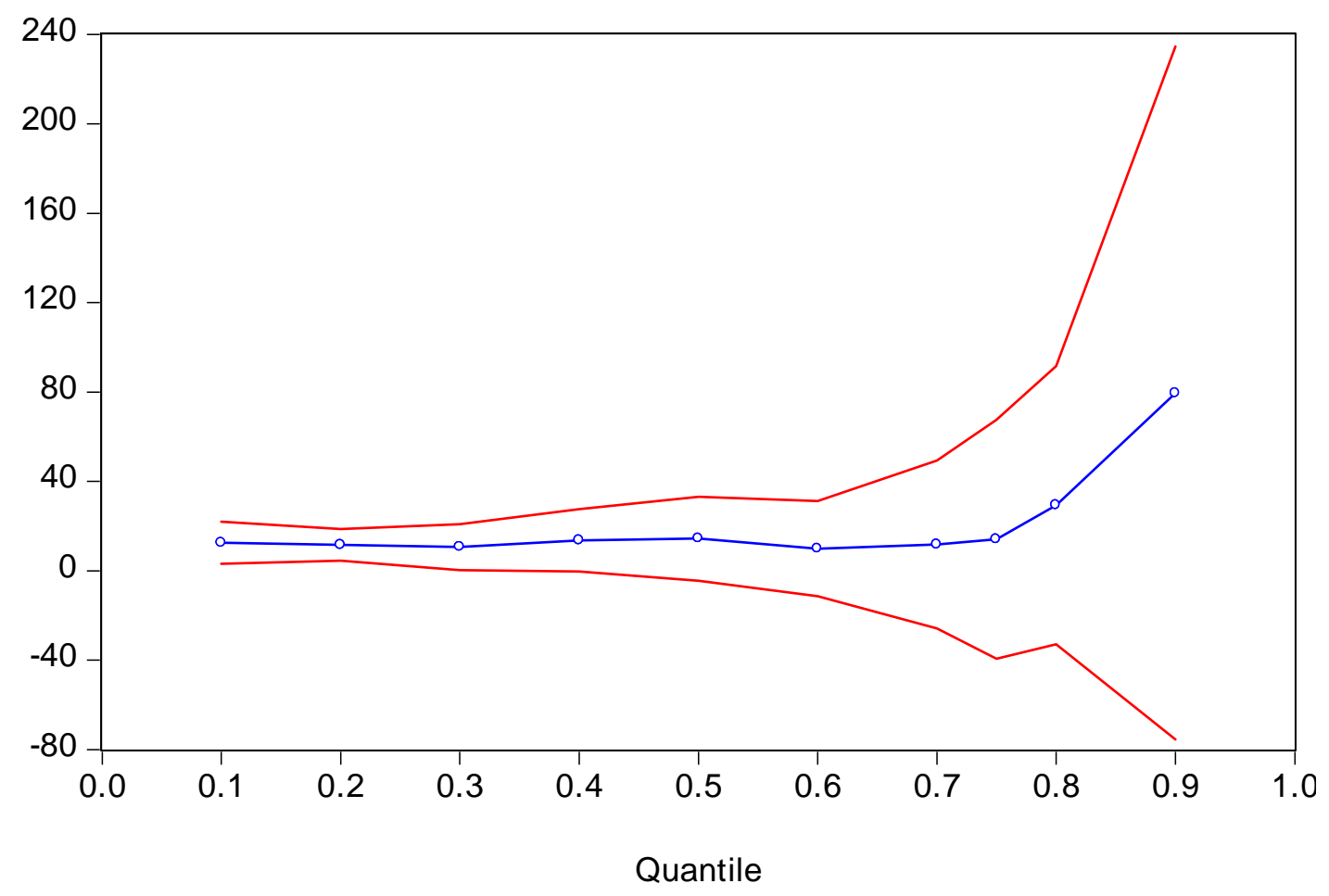

Figure 13

This graph presents the quantile regression estimates of Lerner on NPL for all banks

Quantile Process Estimates for LERNER (95\% Cl)

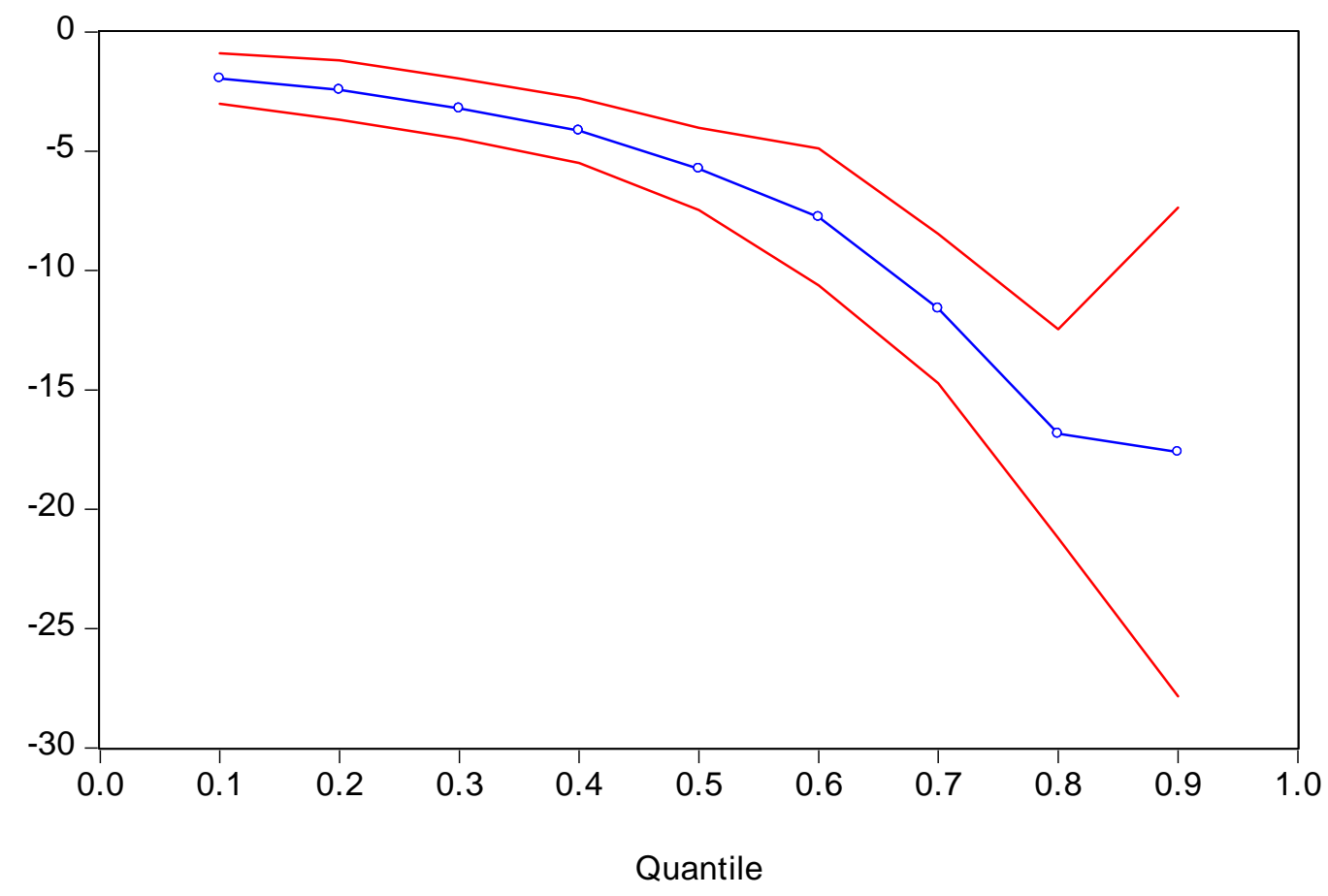


Figure 14

This graph presents the quantile regression estimates of Lerner on NPL for conventional banks

Quantile Process Estimates for LERNER $(95 \% \mathrm{Cl})$

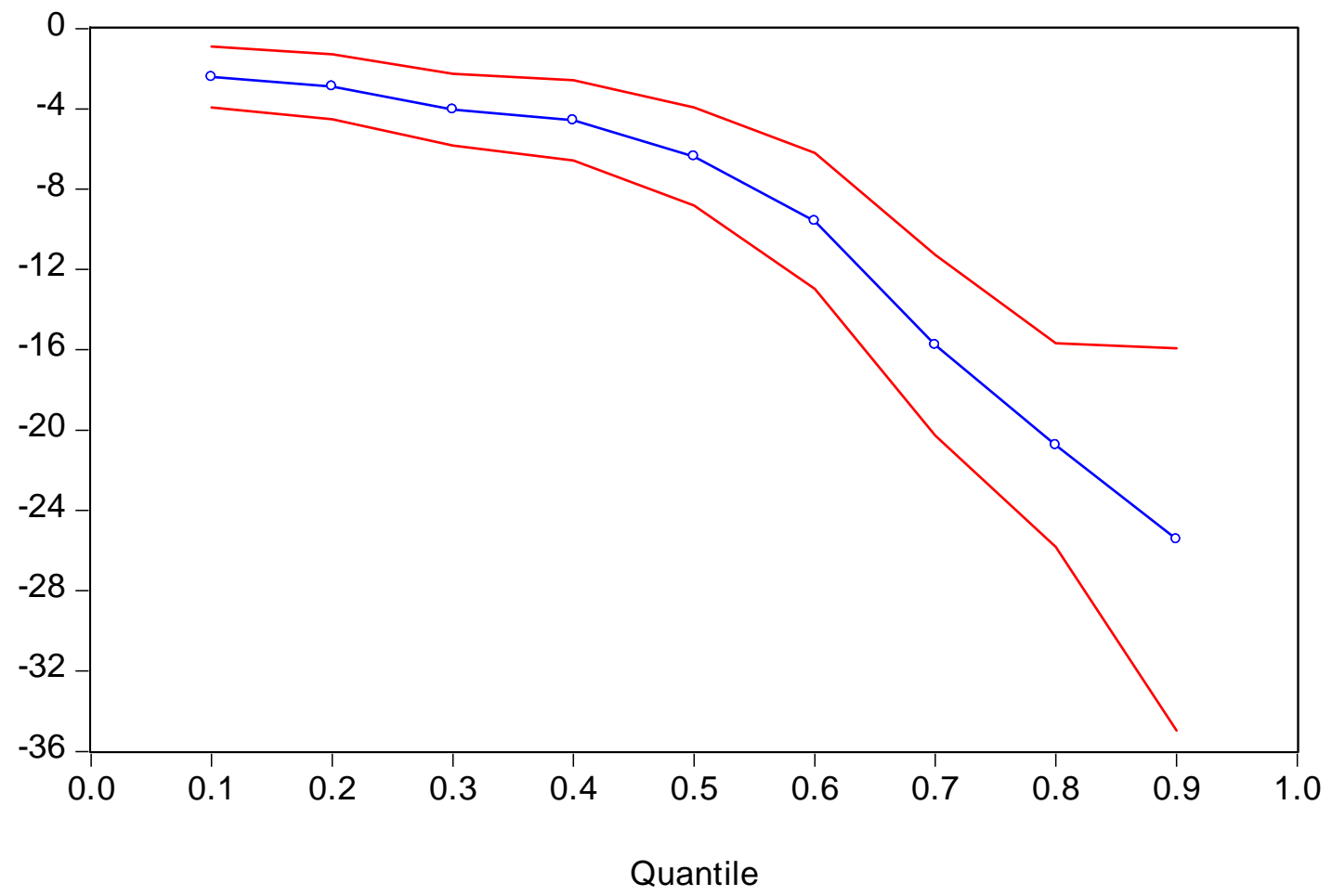

Figure 15

This graph presents the quantile regression estimates of Lerner on NPL for Islamic banks Quantile Process Estimates for LERNER (95\% Cl)

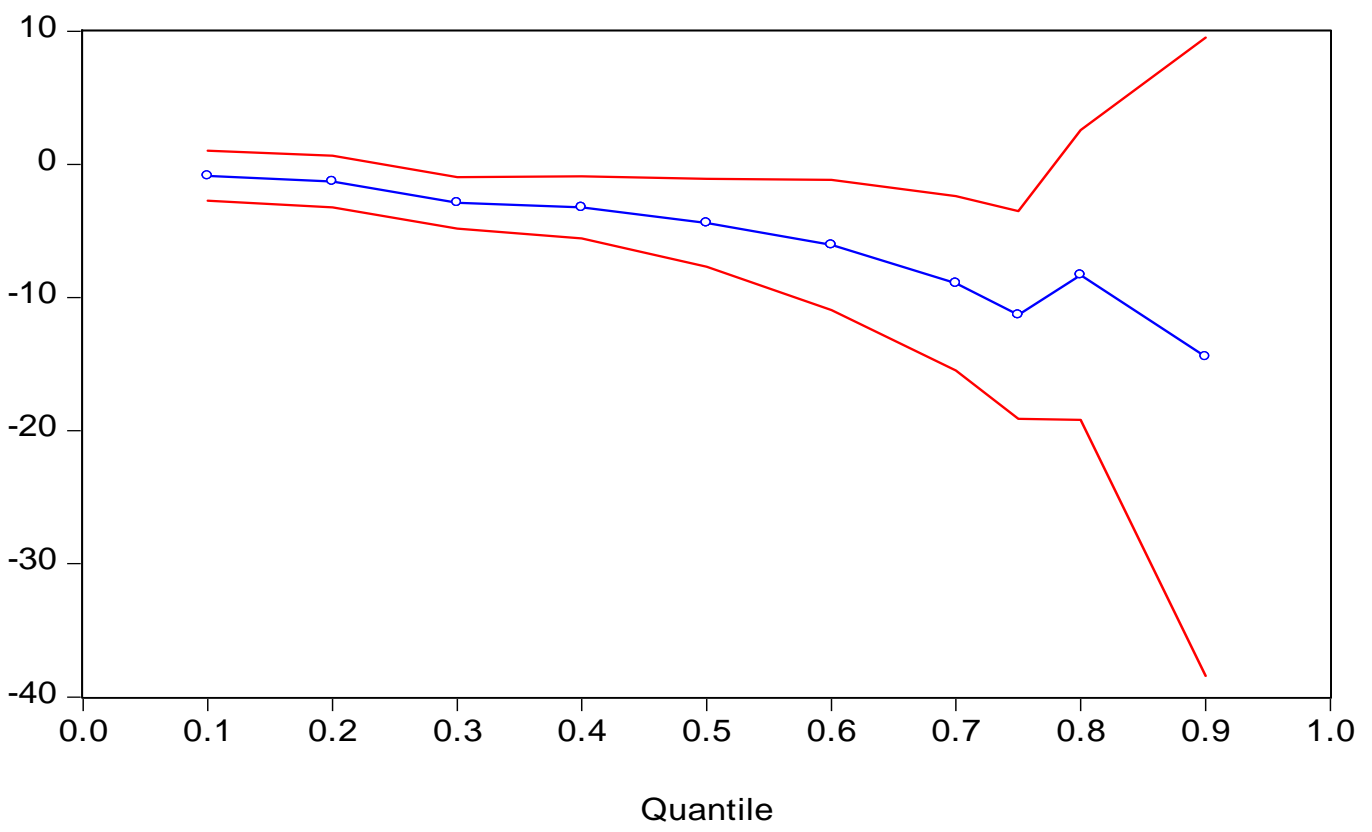


Figure 16

This graph presents the quantile regression estimates of Lerner on DD for all banks

Quantile Process Estimates for LERNER (95\% Cl)

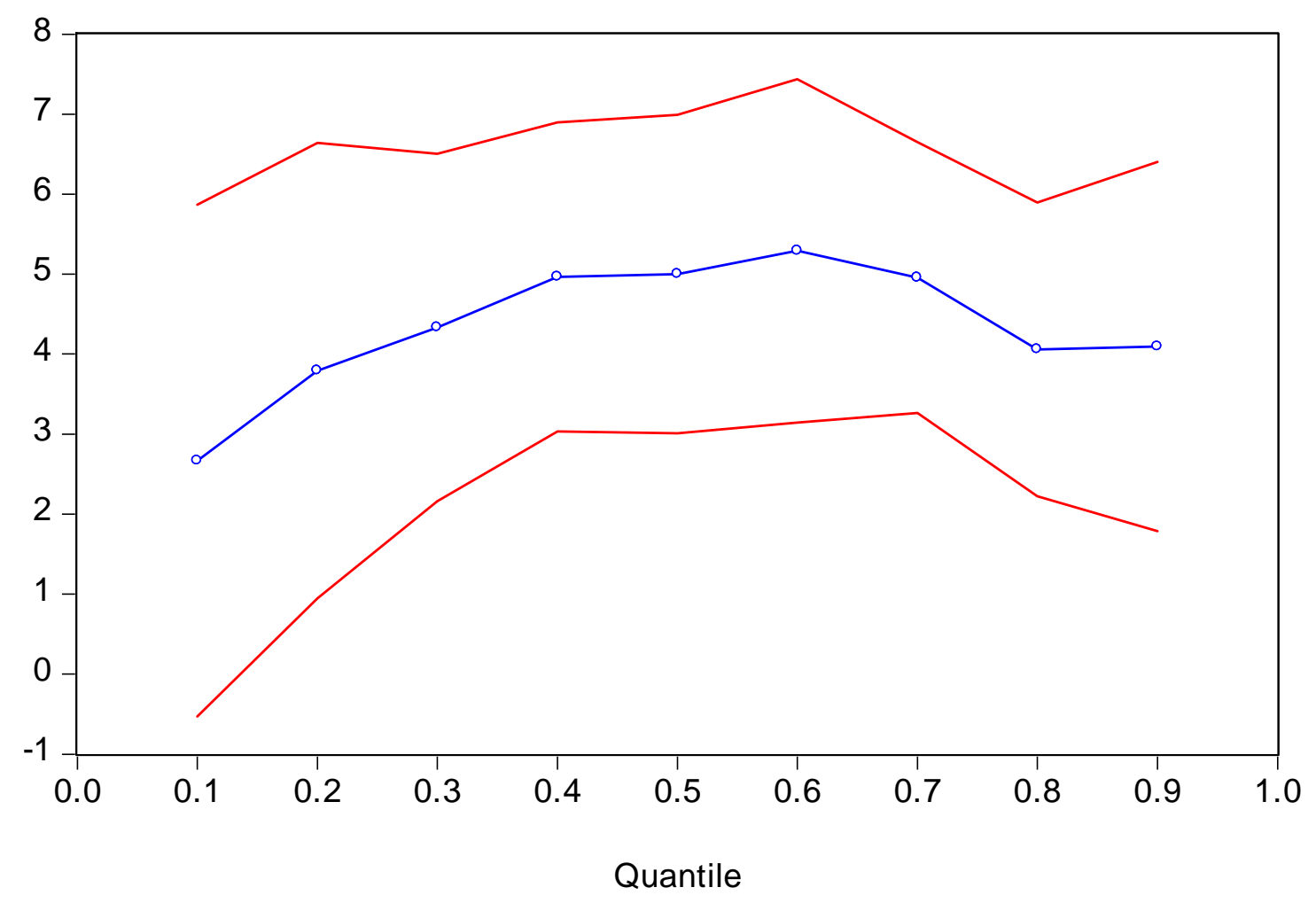

Figure 17

This graph presents the quantile regression estimates of Lerner on DD for conventional banks Quantile Process Estimates for LERNER (95\% Cl)

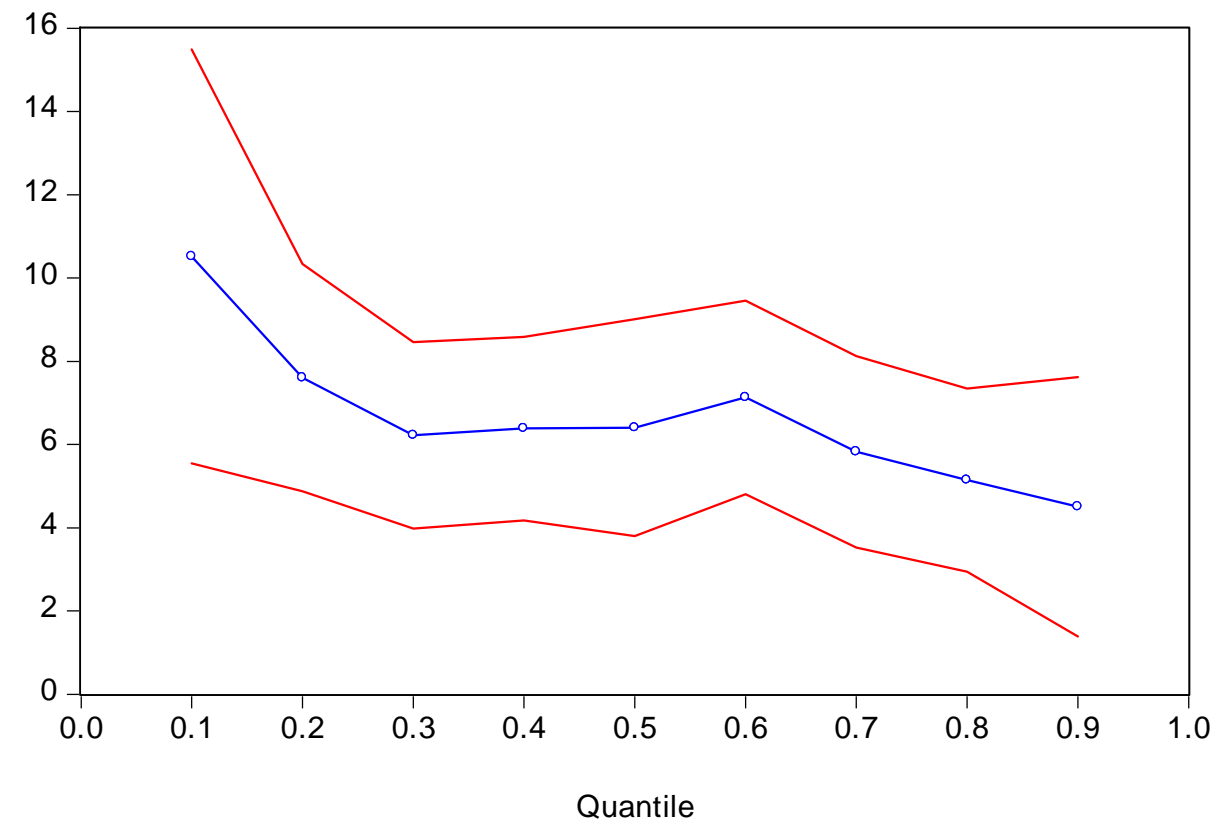


Figure 18

This graph presents the quantile regression estimates of Lerner on DD for Islamic banks Quantile Process Estimates for LERNER (95\% Cl)

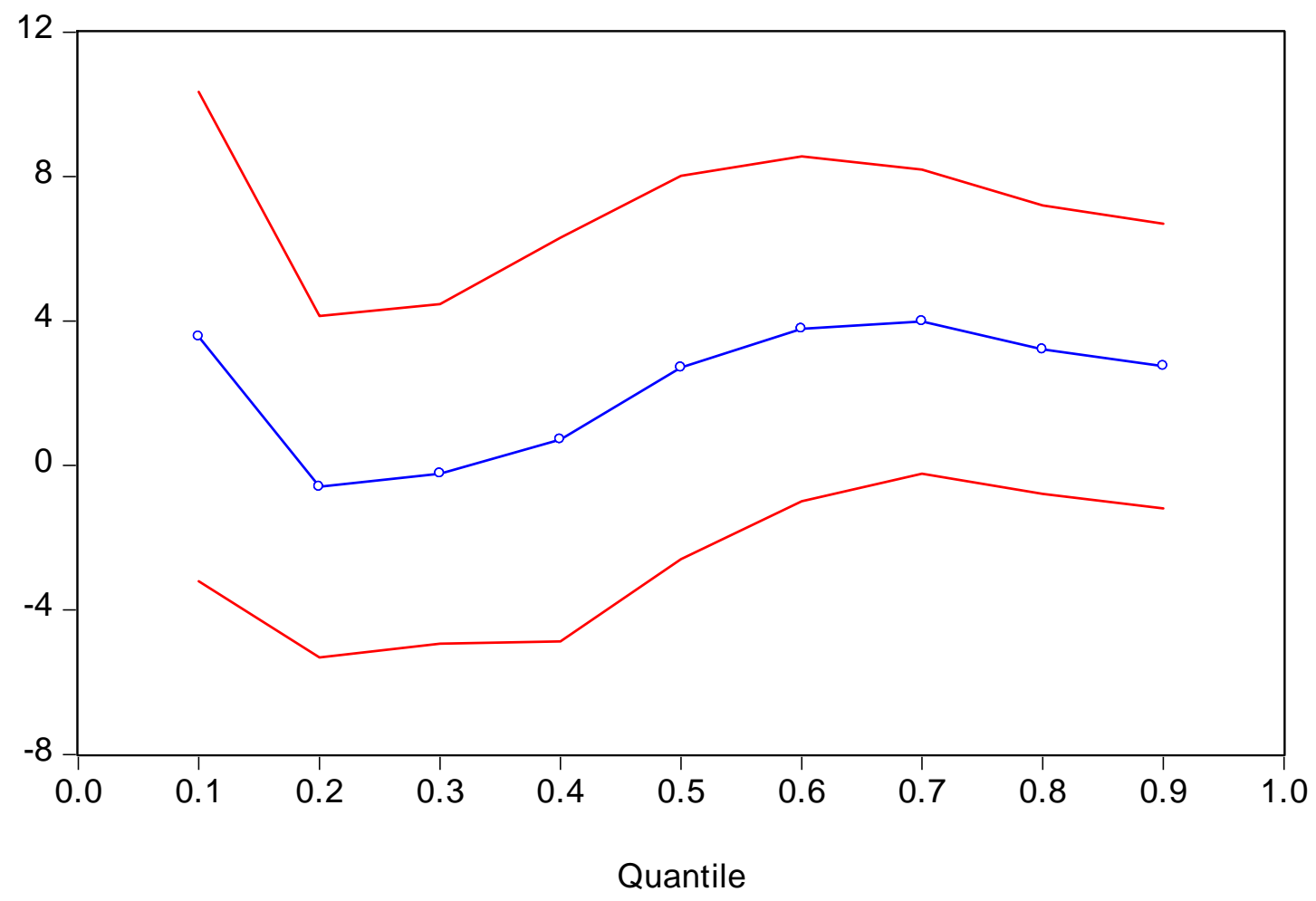

